University of Michigan Law School

University of Michigan Law School Scholarship Repository

Law \& Economics Working Papers

$10-1-2010$

\title{
Securities Law in the Roberts Court: Agenda or Indifference?
}

\author{
Adam C. Pritchard \\ University of Michigan Law School, acplaw@umich.edu
}

Follow this and additional works at: https://repository.law.umich.edu/law_econ_current

Part of the Securities Law Commons

\section{Working Paper Citation}

Pritchard, Adam C., "Securities Law in the Roberts Court: Agenda or Indifference?" (2010). Law \& Economics Working Papers. 25.

https://repository.law.umich.edu/law_econ_current/art25

This Article is brought to you for free and open access by University of Michigan Law School Scholarship Repository. It has been accepted for inclusion in Law \& Economics Working Papers by an authorized administrator of University of Michigan Law School Scholarship Repository. For more information, please contact mlaw.repository@umich.edu. 


\title{
Securities Law in the Roberts Court: Agenda or Indifference?
}

\author{
A.C. Pritchard* \\ Draft \#6 \\ October 2010
}

* Frances and George Skestos Professor of Law, University of Michigan. This paper was prepared for the Business Law in the Roberts Court Conference held at the Case Western Reserve University School of Law sponsored by the Searle Freedom Trust. Thanks to participants at that conference for helpful comments, as well as Luis Delatorre. Please send comments to acplaw@umich.edu 


\section{Introduction}

To outsiders, securities law is not all that interesting. The body of the law is made up of an interconnecting web of statutes and regulations that fit together in ways that are decidedly counter-intuitive. Securities law rivals tax law in its reputation for complexity and dreariness. Worse yet, the subject regulated - the capital markets - can be mystifying to those uninitiated in modern finance theory. Moreover, those markets are rapidly evolving and increasing in their complexity. If you do not understand how the financial markets work, it is hard to understand how securities law affects those markets.

Nothing in the biographies of the current members of the Supreme Court suggest they are likely to be either interested, or well equipped, to deal with the federal securities laws. This lacunae of securities expertise is a relatively recent phenomenon. For most of the first fifty years after the federal securities laws were adopted, the Court had at least one justice with a background in the securities laws, either as a regulator - William 0. Douglas $^{1}$ or as a practitioner - Lewis F. Powell, Jr. ${ }^{2}$

Powell's retirement left the Rehnquist Court with a void in this regard for most of its tenure, and his departure marked a significant decline in the Court's securities caseload, as demonstrated by Table 1 below. Usually the justices' collective lack of familiarity with the securities laws means that few petitions for certiorari are granted in securities cases; the Court simply does not decide that many cases in the field. As Table 1 below demonstrates, the

\footnotetext{
${ }^{1}$ A caveat is in order here; despite Douglas's background as SEC Chairman, he exhibited little interest in the securities laws during his time on the Court. See A.C. Pritchard \& Robert P. Thompson, Securities Law and the New Deal Justices, 95 Va. L. Rev. 841 (2009).

${ }^{2}$ On Powell's influence on the Court's securities law jurisprudence, see A.C. Pritchard, Justice Lewis F. Powell, Jr. and the Counter-Revolution in the Federal Securities Laws, 52 Duke L.J. 841 (2003).
} 


\section{Securities Law in the Roberts Court}

Rehnquist Court averaged slightly more than one case per term during its nearly twenty year run, a figure consistent with the average number heard by the Warren Court.

Supreme Court Securities Cases, 1936-2010

\begin{tabular}{|l|c|c|c|c|}
\hline \multicolumn{1}{|c|}{ Court } & $\begin{array}{c}\text { Securities } \\
\text { Cases }\end{array}$ & $\begin{array}{c}\text { Average Per } \\
\text { Term }\end{array}$ & Total Cases & $\begin{array}{c}\text { Securities } \\
\text { Percent }\end{array}$ \\
\hline $\begin{array}{l}\text { New Deal } \\
(1936-1954)\end{array}$ & 21 & 1.11 & 2,894 & $0.7 \%$ \\
\hline $\begin{array}{l}\text { Warren } \\
(1954-1969)\end{array}$ & 17 & 1.06 & 3,491 & $0.5 \%$ \\
\hline $\begin{array}{l}\text { Burger } \\
(1969-1986)\end{array}$ & 49 & 2.72 & 3,828 & $1.3 \%$ \\
\hline $\begin{array}{l}\text { Rehnquist } \\
(1986-2005)\end{array}$ & 20 & 1.00 & 2,173 & $0.9 \%$ \\
\hline $\begin{array}{l}\text { Roberts } \\
(2005-2010)\end{array}$ & 9 & 1.80 & 388 & $2.3 \%$ \\
\hline \multicolumn{1}{c|}{ Total } & 116 & 1.55 & 12,564 & $0.9 \%$ \\
\hline
\end{tabular}

The first five years of the Roberts Court have departed from that long-term pattern, at least in terms of securities case load. The Roberts Court has decided a whopping nine cases in the field of securities law, $2.3 \%$ of its docket. That increase suggests the justices have taken a new interest in the field, despite the lack of a justice with a background in securities law.

Does this upsurge in securities cases reflect a new agenda for the Supreme Court in the field of securities law? A closer examination of the cases suggests that the numbers may be deceptive. As Table 2 demonstrates, no single justice has stepped forward to take charge of the field of securities regulation as Powell did during his time on the Burger Court. Only Justice Breyer has written more than one majority opinion in the area. Justice Stevens appears to be engaged with the field, but most of his seven opinions in the field have been dissents or concurrences; his interest does not translate into influence, as it did for Powell. 


\section{Securities Law in the Roberts Court}

Roberts Court Securities Cases, 2005-2010

\begin{tabular}{|l|l|l|l|}
\hline Decision & Majority & \multicolumn{1}{|c|}{ Dissent } & \multicolumn{1}{|c|}{ Concur } \\
\hline Merrill Lynch v. Dabit & Stevens & & \\
\hline Kircher v. Putnam Funds Trust & Souter & & Scalia \\
\hline Credit Suisse Securities v. Billing & Breyer & Thomas & Stevens \\
\hline Tellabs v. Makor Issues \& Rights & Ginsburg & Stevens & Scalia, Alito \\
\hline Stoneridge Inv. Part. v. Scientific-Atlanta & Kennedy & $\begin{array}{l}\text { Stevens, Souter, } \\
\text { Ginsburg }\end{array}$ & \\
\hline Jones v. Harris Associates & Alito & Thomas \\
\hline Merck \& Co. v. Reynolds & Breyer & $\begin{array}{l}\text { Stevens, Scalia, } \\
\text { Thomas }\end{array}$ \\
\hline Morrison v. National Australia Bank & Scalia & Stevens & $\begin{array}{l}\text { Breyer, Stevens, } \\
\text { Ginsburg }\end{array}$ \\
\hline Free Enterprise Fund v. PCAOB & Roberts & Breyer, Stevens, & \\
\hline
\end{tabular}

Opinion authors in bold.

When one turns to the substance of the opinions written in these cases, one finds little effort to grapple with the relation between the financial markets and the securities laws. There are vigorous debates among the justices in some of these cases, but they revolve around questions of statutory interpretation and the relationship between the judiciary and the administrative state. The overall theme might be characterized as one of judicial modesty.

One exception to this pattern of judicial modesty, would appear to be the topic of securities class actions. The passage of the Private Securities Litigation Reform Act in 1995 (PSLRA), ${ }^{3}$ and its follow-on, the Securities Litigation Uniform Standards Act in 1998 (SLUSA), ${ }^{4}$

\footnotetext{
${ }^{3}$ Pub. L. No. 104-67, 109 Stat. 737 (1995) (codified as amended in scattered sections of 15 U.S.C.).

${ }^{4}$ Pub. L. No. 105-353, 112 Stat. 3227 (1998).
} 


\section{Securities Law in the Roberts Court}

have generated a number of interpretive opportunities for the Roberts Court. Most of these cases have revolved around straightforward issues of statutory interpretation, but on occasion the issues raised by these statutes have forced the justices to grapple with the policy implications of their decisions for securities class action practice. Those decisions have caused critics to label the Roberts Court as "pro business." ${ }^{5}$ Does the "pro business" Roberts Court have a negative attitude toward securities class actions? An examination of the overall pattern of the Court's decisions in this area suggests a bias toward the status quo, resisting attempts to both expand - and restrict - the reach of Rule 10b-5 class actions.

I proceed as follows. The justices' debates over the appropriate method of interpreting statutes are analyzed In Part 2. Part 3 looks at the perspective on the administrative state offered in the Roberts Court's securities decisions. Part 4 assesses whether the Roberts Court has taken a hostile attitude toward securities class actions. Part 5 concludes.

\footnotetext{
${ }^{5}$ See, e.g., New York Times, First Monday (Oct. 3, 2010) ("The Roberts court has championed corporations.").
} 


\section{Securities Law in the Roberts Court}

\section{Statutory Interpretation and Legislative Intent}

Three of the securities cases decided during Chief Justice Roberts's tenure have turned exclusively on questions of statutory interpretation. More precisely, these cases have turned on the Court's assumptions about what Congress intended when it used specific statutory language. That language was adopted against a backdrop of judicial interpretations of similar language; the opinions purport to erect a predictable framework of interpretation. These opinions betray no indication that the Roberts Court is attempting to push the securities laws in a particular direction. The lack of an agenda in the opinions is reinforced by another common thread; the petitions for certiorari were granted by the Court only after a clear conflict had arose in the circuits over the particular question of statutory interpretation involved in each case. These cases are decided because the justices felt obligated to resolve the split, not because any member of the Court had a particular interest in the securities topic presented.

\section{A. SLUSA}

Chief Justice Roberts' first term brought two securities cases to the Court's docket, both involving interpretive issues arising out of SLUSA. A brief introduction to SLUSA is necessary to understand the issues in these cases. Congress adopted SLUSA in 1998, three years after enacting the PSLRA. The PSLRA made it more difficult to allege securities fraud by: (1) adopting a more stringent pleading standard, including heightened requirements for pleading scienter, i.e., state of mind; ${ }^{6}$ and (2) creating an automatic stay of discovery. ${ }^{7}$ Those restrictions under federal law gave rise to an exodus of securities class actions to state court; state "blue sky" anti-

\footnotetext{
${ }^{6}$ Exchange Act § 21D (b) (1); 15 U.S.C. §78-u4(b)(1).
}

${ }^{7}$ ld. at $\S 21 \mathrm{D}(\mathrm{b})(3)(\mathrm{B})$. 
fraud provisions generally lack the procedural protections that the PSLRA affords defendants in the federal securities class actions. ${ }^{8}$ The goal of SLUSA was to preempt state law securities cases thereby pushing plaintiffs back to federal court where the restrictions of the PSLRA would apply. $^{9}$

Congress did not, however, preempt the substantive law of state securities fraud or its remedies. Instead, it preempted a certain procedure employed by state courts in adjudicating securities fraud cases: class actions. ${ }^{10}$ In targeting only securities fraud class actions, Congress left state law to provide a cause of action for securities fraud, albeit one that can only be pursued individually. SLUSA preempts class actions:

based upon the statutory or common law of a State or subdivision thereof . . . by any private party alleging -

(A) a misrepresentation or omission of a material fact in connection with the purchase or sale of a covered security; or

(B) that the defendant used or employed any manipulative or deceptive device or contrivance in connection with the purchase or sale of a covered security.

Although the language is not identical, SLUSA's preemption language tracks closely the general federal anti-fraud prohibition found in $\$ 10(b)$ of the Exchange Act and the SEC's Rule 10b-5, Rule $10 \mathrm{~b}-5$ is the typical basis for federal securities class actions. ${ }^{11}$

1. Merrill Lynch, Pierce, Fenner \& Smith v. Dabit

Merrill Lynch, Pierce, Fenner \& Smith v. Dabit ${ }^{12}$ raised the question of the scope of SLUSA's preemption. The case arose out of the securities analyst scandals of the early 2000 s, in

\footnotetext{
${ }^{8}$ See generally David M. Levine \& A.C. Pritchard, The Securities Litigation Uniform Standards Act of 1998: The Sun Sets on California's Blue Sky Laws, 54 Bus. Law. 1 (1998).

${ }^{9}$ See Joint Explanatory Statement, H.R. Rep. 105-803 (Oct. 9, 1998) ("The purpose of this title is to prevent plaintiffs from seeking to evade the protections that Federal law provides against abusive litigation by filing suit in State, rather than in Federal, court.").

${ }^{10}$ Securities Act § 16(f)(2)(A); 15 U.S.C. § 77p(f)(2)(A))

1117 C.F.R. § 240.10b-5.
} 


\section{Securities Law in the Roberts Court}

which the New York attorney general and the SEC alleged that securities analysis provided by the major investment banks was biased as a result of those banks' conflict of interest. Essentially, the government alleged that the banks were hyping the common stock of their investment banking clients in order to garner more investment banking business. The government enforcement actions were followed by a host of private claims, which were asserted in both federal securities class actions and arbitration proceedings. The scandal also gave rise to the claim in Dabit: plaintiffs alleged that they were induced to hold securities that they would have sold if the analyst research that they relied upon had been accurate. ${ }^{13}$

Plaintiffs' complaint was a transparent attempt to evade SLUSA's restrictions, but it gave rise to an interpretive difficulty. SLUSA preempts only claims that are "in connection with the purchase or sale of a covered security;" plaintiffs were claiming that they had not sold their securities. Moreover, the claim being asserted could not have been raised under federal law. In Blue Chip Stamps v. Manor Drug Stores the Supreme Court held that plaintiffs must have sold or purchased securities in order to have standing under Rule $10 \mathrm{~b}-5 .^{14}$ Would Blue Chip's narrow interpretation of "in connection with the purchase or sale of a security" undercut the preemptive force of SLUSA?

Ultimately, Justice Stevens, writing for the Court was forced to engage in judicial "reimagination" of Congress's intent. No one seriously doubted that Congress, if it had considered the question, would have preempted such claims: the point of SLUSA was to protect issuers from meritless suits by funneling securities class actions into federal court. In addition,

\footnotetext{
${ }^{12} 547$ U.S. 71 (2006).

${ }^{13}$ Dabit, 547 U.S. at 75.

${ }^{14} 421$ U.S. 723 (1975).
} 


\section{Securities Law in the Roberts Court}

the economic logic of holder claims is dubious at best. Allowing compensation for holder claims would amount to a windfall - I would have sold if I had known the truth! (And the purchaser would not have known?) Presumably Congress did not anticipate the problem of holder suits because of the scant likelihood that any state court would allow such claims. The Court notes that Congress had no occasion to consider whether holder claims should be preempted at the time it adopted SLUSA: "the actual assertion of such claims by way of class action was virtually unheard of before SLUSA was enacted."15 ${ }^{15}$ otwithstanding the novelty of such claims, it was clear to the Court that "[a] narrow reading of the statute would undercut the effectiveness of the 1995 Reform Act and thus run counter to SLUSA's stated purpose, viz.., 'to prevent certain State private securities class action lawsuits alleging fraud from being used to frustrate the objectives of the [PSLRA].'"16

Fortunately for the Court, it was able to rely on prior interpretations of Rule $10 \mathrm{~b}-5$ that had also loosened the requirement of a purchase or sale. The Court had previously interpreted Rule $10 b-5$ to not require the allegation of a specific purchase or sale of a security - at least in a government enforcement action. According to the Court, "[u]nder our precedents, it enough that the fraud alleged 'coincide' with a securities transaction - whether by the plaintiff or someone else."17 Thus, the Court had two interpretations of Rule $10 \mathrm{~b}-5$ that it could look to in interpreting the essentially identical language used by Congress in SLUSA: the first, the construction of the private right of action, and the second, purporting to construe only $\S 10(b)$ 's text, which applied only to government actions. At first glance, one might have thought the

\footnotetext{
${ }^{15}$ Dabit, 547 U.S. at 88.

${ }^{16}$ Dabit, 547 U.S. at 86 (quoting SLUSA § 2(5), 112 Stat. 3227).

${ }^{17}$ Dabit, 547 U.S. at 85 (citing United States v. O'Hagan, 521 U.S. 642, 651 (1997)
} 


\section{Securities Law in the Roberts Court}

interpretation used for the private right of action was the most applicable; the Court was, after all, addressing a private right of action, albeit one arising under state law. The Court, however, chose the broader interpretation of $\S 10(b)$ in defining SLUSA's scope, it offered two reasons in support of that interpretive choice.

Both justifications are open to criticism. The first offered was that the broader position was consistent with the SEC's longstanding interpretation. ${ }^{18}$ Of course, the SEC's interpretation arose out of government actions, so it is hard to see why it should guide the interpretive choice being made here. Second, the Court conjectured that "Congress can hardly have been unaware of the broad construction adopted by both this Court and the SEC when it imported the key phrase- 'in connection with the purchase or sale' into SLUSA's core provision." ${ }^{19}$ This conjecture is open to question - it seems to posit an ideal legislator who pays careful attention to judicial interpretations - but more importantly, it does not answer the question of which interpretation Congress is presumed to be aware of. Why not both? And why presume that Congress favored one over the other? With two interpretations available, Stevens chose the one consistent with the statute's obvious purpose. The inclusion of that purpose in the text of the statute meant there would be no debates over how to read legislative intent, a topic that would arise in later cases; that intent was included in the statute enacted by Congress and signed into law by the President. As a result, Stevens was able to attract a unanimous Court for his opinion. $^{20}$

\section{Kircher v. Putnam Funds Trust}

\footnotetext{
${ }^{18}$ Dabit, 547 U.S. at 85.

${ }^{19}$ Dabit, 547 U.S. at 85.

${ }^{20}$ Justice Alito did not participate, having joined the Court after oral argument.
} 
The Court's second foray into SLUSA was almost unanimous, with only Justice Scalia declining to join the majority opinion. Kircher v. Putnam Funds Trust called on the Court to interpret SLUSA's removal provision. ${ }^{21}$ SLUSA bolsters its preemptive effect with the option of removal to federal court. ${ }^{22}$ The provision is somewhat unusual in that is allows for removal of actions so that they can be dismissed in federal court. Ordinarily, one would expect the law to require the defendant to bring its motion to dismiss or demurrer in state court. Indeed, SLUSA appears to strip the state court of subject matter jurisdiction; ordinarily, the state court would dismiss the case, even on its own motion.

The removal provision, however, serves two important federal interests: (1) it allows federal courts to interpret the scope of preemption, thus enhancing uniformity; and (2) it triggers the PSLRA's stay of discovery. SLUSA contains a number of exceptions to its preemptive reach, so there is some federal interest in uniformity of interpretation. The more pressing interest for defendants, however, is the ability to block discovery. Some state court rules would allow discovery while a motion to dismiss was pending, thus forcing the defendant to seek a discretionary stay from the state court or an injunction against discovery from a federal court under SLUSA. ${ }^{23}$ That discovery could be used, not only in the state court action, but also in a subsequent federal class action. Removal allows the defendant to file a motion to dismiss in federal court which automatically triggers the federal discovery stay under the PSLRA. Thus, removal to federal court allows Congress to protect issuers against the costs of

\footnotetext{
${ }^{21} 547$ U.S. 633 (2006).

22 Securities Act $\S 16(c) ; 15$ U.S.C. $\S 77 p(c)$ ) ("Any class action brought in any State court involving a covered security, as set forth in subsection (b), shall be removable to the Federal district court for the district in which the action is pending, and shall be subject to subsection (b).").

${ }^{23}$ The injunction against discovery may or may not be available, depending on whether a parallel action has been filed in federal court.
} 


\section{Securities Law in the Roberts Court}

"fishing expedition" discovery without further interfering with state courts by limiting the availability of discovery there.

This removal provision, however, raises the question of the appropriate response to improperly removed cases, i.e., a case not within the scope of SLUSA's preemption. If a nonpreempted action has been removed erroneously to federal court, SLUSA allows the federal court to remand the action to state court. ${ }^{24}$ In Kircher, the district court remanded the case to state court after determining that federal jurisdiction was lacking. ${ }^{25}$ Defendants appealed to the Seventh Circuit, which held that the claims were precluded by SLUSA. ${ }^{26}$

To reach that conclusion, however, the Seventh Circuit first had to determine that it had jurisdiction to hear the appeal. This question was complicated by 28 U.S.C. $\S 1447(d)$, which bars appellate review of district court orders remanding for lack of subject matter jurisdiction. The Seventh Circuit held the question of preclusion to be distinct from the question of jurisdiction, and therefore reviewable on appeal. ${ }^{27}$

The Supreme Court disagreed, noting that the Court had "relentlessly repeated" that remand orders are not subject to appellate review. ${ }^{28}$ That consistent approach meant "Congress is aware of the universality of th[e] practice of denying appellate review of remand orders when Congress creates a new ground for removal." 29 The Court found no "clear

\footnotetext{
${ }^{24}$ Securities Act § 16(d)(4); 15 U.S.C. § 77p(d)(4))

${ }^{25}$ The district court's decision which was based on the fact that plaintiff had not purchased or sold securities, preceded the Court's Dabit decision rejecting that interpretation of SLUSA's preemptive language. Kircher, 547 U.S. at 638 n. 5.

${ }^{26} 403$ F.3d 478 (2005).

${ }^{27} 373$ F.3d 847 (2004).

${ }^{28}$ Kircher, 547 U.S. at $640-641$ \& n. 8

${ }^{29}$ Kircher, 547 U.S. at 640-641 \& n. 8
} 


\section{Securities Law in the Roberts Court}

statutory command" in SLUSA to overcome that presumption. ${ }^{30}$ The Court read the statute's removal provision to be coextensive with its preclusion provision: "Once removal jurisdiction under subsection (c) is understood to be restrict to precluded actions defined by subsection (b), a motion to remand claiming the action is not precluded must be seen as posing a jurisdictional issue. ${ }^{31}$ If not precluded, then no jurisdiction. Consequently, the district court's remand order was not subject to review in the court of appeals. Moreover, federal courts were not given exclusive authority to address the question of preclusion; the Court read the statute as allowing the defendant to seek dismissal in state court without first removing to federal court. ${ }^{32}$ Few defendants will opt to do this, but it does mean that the state court will have jurisdiction to dismiss a preempted claim.

The only aspect of the case that generated any dispute among the justices was the question of what was needed to trigger the rule of no appellate review. Justice Scalia wrote a concurrence to offer his view that it did not matter whether the remand was based on lack of jurisdiction or not. ${ }^{33}$ As long as the district court stated that the remand was based on lack of jurisdiction, that was sufficient to invoke the rule of no appellate review. ${ }^{34}$ The interpretation of SLUSA was unimportant for Scalia; what mattered in the case was the enforcement of the rule of no appellate review for remand orders.

The justices were in unanimous agreement that there is nothing special - nothing inherently federal - about SLUSA. It is a federal law, preempting certain state court actions, but

\footnotetext{
${ }^{30}$ Kircher, 547 U.S. at 641 n. 8.

${ }^{31}$ Kircher, 547 U.S. at 643-644.

${ }^{32}$ Kircher, 547 U.S. at 646

${ }^{33}$ Kircher, 547 U.S. at 648.

${ }^{34}$ Kircher, 547 U.S. at 649-650.
} 


\section{Securities Law in the Roberts Court}

it can be applied by either federal or state courts, at the defendant's option. The ordinary rules of appellate (non)review are deemed to apply. No one on the Court saw any value in having federal courts as the exclusive interpreters of SLUSA's reach, and no one mentioned the need to enforce the discovery stay as a justification for keeping the case in the federal courts until the question of preemption was resolved. The Court was focused on its jurisprudence relating to remand orders, not the task of implementing SLUSA to craft a coherent federal securities class action regime.

\section{B. Statute of Limitations}

The statute of limitations in Rule $10 \mathrm{~b}-5$ cases has a somewhat convoluted history. Given that the Rule $10 \mathrm{~b}-5$ cause of action was created by the judiciary, rather than Congress, it is hardly surprising that Congress did not specify a limitations period for $\S 10$ (b) when it passed the Exchange Act in 1934. When confronted with the issue, the Court borrowed the Exchange Act provision applicable to securities price manipulation claims, ${ }^{35}$ which requires that suits be brought "within one year after the discovery of the facts constituting the violation and within three years after such violation." ${ }^{36}$ Congress claimed the issue for itself, however, when it passed the Sarbanes-Oxley Act in 2002 in the wake of the Enron and WorldCom scandals. ${ }^{37}$ That law extended the limitations period for $\S 10(b)$ actions to " 2 years after the discovery of the facts constituting the violation" or "5 years after such violation."

\footnotetext{
${ }^{35}$ Lampf, Pleva, Lipkind, Prupis \& Pettigrow v. Gilbertson, 501 U.S. 350 (1991).

${ }^{36} 15$ U.S.C. $\S 78 \mathrm{i}((\mathrm{e})$

${ }^{37}$ Sarbanes-Oxley Act $\S 804,116$ Stat. 801 (2002), codified at 28 U.S.C. $§ 1658(b)$.
} 


\section{Securities Law in the Roberts Court}

Merck \& Co. Inc. v. Reynolds called on the Roberts Court to interpret both "discovery" and "facts constituting the violation" as used in this provision. ${ }^{38}$ On the first point, the Court had to resolve the uncertainty over whether discovery required actual discovery of the facts by the plaintiff, or whether it should extend to facts that a "reasonably diligent plaintiff would have discovered." ${ }^{39}$ On its face, this would not seem to be much of an issue, as the parties (along with the Solicitor General) agreed that the latter interpretation was correct. ${ }^{40}$ Justice Breyer, however, addressed the issue at length, purportedly "because we cannot answer the question presented without considering whether the parties are right about this matter." The more likely explanation, however, is that Justice Scalia (joined by Justice Thomas) disagreed on this point. Scalia wrote separately to argue that discovery meant discovery by the actual plaintiff in the case. ${ }^{41}$

The justices disagreed on the meaning of discovery because of their differing approaches to statutory interpretation. For Breyer and the majority, the reasonably diligent discovery standard made sense because lower courts had followed that approach prior to the passage of the Sarbanes-Oxley Act. ${ }^{42}$ "We normally assume that, when Congress enacts statutes, it is aware of relevant judicial precedent." ${ }^{43}$ The Court concluded that Congress had codified that precedent.

Scalia rejected the majority's approach:

Even assuming that Congress intended to incorporate the Circuits' views - which requires the further unrealistic assumption that a majority of each House knew

\footnotetext{
38130 s. Ct. 1784.

${ }^{39}$ Merck, $130 \mathrm{~S}$. Ct. at 1793.

${ }^{40}$ Merck, 130 S. Ct. at 1793.

${ }^{41}$ Merck, 130 S. Ct. at 1800 (Scalia, J., concurring) .

${ }^{42}$ Merck, 130 S. Ct. at 1795.

${ }^{43}$ Merck, 130 S. Ct. at 1795.
} 


\section{Securities Law in the Roberts Court}

of and agreed with the Courts of Appeals' opinions - that would be entirely irrelevant. Congress's collective intent (if such a thing even exists) cannot trump the text it enacts, and in any event we have no reliable way to ascertain that intent apart from reading the text. ${ }^{44}$

Scalia's preferred approach: locate the statute of limitations adopted by Congress in the overall statutory scheme. Included in this scheme, in Scalia's view, were not only the other provisions of the Exchange Act, but also the Securities Act. Bringing the Securities Act into the picture changes the analysis because that law includes an explicit constructive discovery provision in $\S$ 13. The limitations period begins to run "after the discovery of the untrue statement or the omission, or after such discovery should have been made by the exercise of reasonable diligence." $^{45}$ For Scalia, Congress's inclusion of a constructive discovery provision in the Securities Act's statute of limitations meant that its omission in the analogous provision of the Exchange Act must be given legal effect, i.e., constructive discovery would not trigger the statute of limitations period under the Exchange Act. ${ }^{46}$

One might label Breyer's approach to statutory interpretation "judicial centric" and Scalia's "textual centric." Breyer's approach can be criticized for making heroic assumptions about the average legislator's familiarity with the judicial precedents in a given area. If the goal is to further legislative intent, Breyer's postulated intent seems largely fictional. Moreover, Breyer does not consistently take the approach throughout the opinion. Confronted with the question of whether "inquiry notice" suffices to begin the running of the statute of limitations, Breyer downplays the importance of lower court decisions adopting that standard because

\footnotetext{
${ }^{44}$ Merck, 130 S. Ct. at 1802 (Scalia, J., concurring) .

4515 U.S.C. $\S 77 \mathrm{~m}$.

${ }^{46}$ Merck, 130 S. Ct. at 1800 (Scalia, J., concurring) ("To interpret $§ 1658(b)(1)$ as imposing a constructive-discovery standard, one must therefore assume, contrary to common sense, that the same word means two very different things in the same statutory context of limitations periods for securities-fraud actions under the 1933 and 1934 Acts.").
} 


\section{Securities Law in the Roberts Court}

"[w]e cannot reconcile it with the statute, which simply provides that 'discovery' is the event that triggers the 2-year limitations period-for all plaintiffs." ${ }^{47}$ Now he's a textualist? Sometimes the text controls, sometimes prior judicial interpretation controls. Breyer leaves us to guess when to apply which standard.

Scalia candidly concedes that he is uninterested in legislative intent, only in legislative enactments. His textual approach can be criticized for being unrealistic in its assumptions about the competence of legislators to fit together statutory provisions into a coherent whole. The problem becomes more acute when, as is the case with the securities laws, provisions are adopted by different Congresses. In this case, the statute of limitations adopted as part of the Sarbanes-Oxley Act came almost seventy years after the Securities Act. Expecting consistency across that long a period may simply be wishful thinking on Justice Scalia's part.

A more fundamental criticism of Justice Scalia's approach is that it ignores the reality of securities class action practice. If the actual plaintiff must have "discover[ed] ... the facts" to begin the tolling of the statute of limitations, it is hardly a challenge for an enterprising plaintiffs' attorney to search out plaintiffs until he has found one who has not yet discovered the facts. Scalia's approach would render the Exchange Act's statute of limitations a nullity for securities class actions, ${ }^{48}$ leaving only the five-year statute of repose. Even the plaintiffs did not endorse Scalia's approach. What is surprising is that Breyer did not call Scalia on this point. Neither side of the dispute seems interested in - or perhaps aware of - the actual practice of securities litigation.

\footnotetext{
${ }^{47}$ Merck, 130 S. Ct. at 1798.

${ }^{48}$ It would still play a role, however, in individual actions.
} 


\section{Securities Law in the Roberts Court}

The second question at issue in the case - what are the "facts constituting the violation" - provoked no disagreement among the justices. The Court's holding on this point - that scienter is one of the facts constituting the violation ${ }^{49}-$ is unremarkable. Breyer's discussion is notable only in that it invokes the pleading standard from the PSLRA to help interpret the statute of limitations. ${ }^{50}$ The PSLRA's pleading standard requires that facts supporting scienter be plead in the complaint. On this issue, Breyer harmonized the different amendments to the Exchange Act, even though they were enacted by different Congresses. He saw no need, however, to harmonize the Exchange Act's statute of limitations with the one found in the Securities Act. Statutory context apparently matters more within a particular statute than it does across the securities laws as a whole.

C. Statutory Interpretation and the Securities Laws

One common thread running through these three cases is the predominance of questions of statutory interpretation at the expense of how those statutes influence actual practice. This approach suggests a somewhat confined vision of the judicial role; only certain sources are relevant.

In Kircher and Merck, the approach to statutory interpretation was dominated by judicial precedent. Congress was presumed to have incorporated those judicial interpretations into its legislation. Whether any member of Congress was actually aware of that precedent, we do not know.

In Dabit, the Court was faced with two interpretive strands, but the Court nonetheless asserted that Congress was legislating against the backdrop of one strand rather than the other.

\footnotetext{
${ }^{49}$ Merck, 130 S. Ct. at 1796.

${ }^{50}$ Merck, 130 S. Ct. at 1796 (citing 15 U.S.C. $\S 78 u-4(b)(2)$ ).
} 


\section{Securities Law in the Roberts Court}

The Court adopted the interpretive choice that it did because the purpose of the statute - to prevent evasion of the PSLRA - was clear from the face of the statute. The judicial precedent was of little relevance to the decision, but the Court nonetheless felt obliged to invoke it, despite its lack of persuasive force.

The common thread here is that the Court is managing the relationship between itself and Congress. In none of the three cases does the Court demonstrate any awareness - or interest - in the actual practice of securities litigation. It is primarily interested in applying its precedents in a predictable fashion. Whether it succeeds in this task is open to question, but the enterprise is a general one, not securities law specific.

\section{The Administrative State}

During the New Deal, the securities laws were a critical proving ground for the Supreme Court in developing its legal approach to the fledgling administrative state. ${ }^{51}$ Franklin Delano Roosevelt and his administration faced a number of legal challenges to their efforts to tame the financial markets. Most notable was a decade long war over the SEC's efforts to dismantle the giant public utility conglomerates under the authority granted by the Public Utility Holding

Company Act. ${ }^{52}$ The bottom line that emerged from those cases was that the Court was going to defer to the administrative state; the expertise of the SEC was a bedrock belief among the

\footnotetext{
${ }^{51}$ See Pritchard \& Thompson, supra note 1 , at

52 Pub. L. No. 49 Stat. 803 (1935).
} 


\section{Securities Law in the Roberts Court}

New Deal alumni that Roosevelt appointed to the Supreme Court. ${ }^{53}$ That deference translated into a stellar track record for the SEC; the agency rarely lost a case in its first four decades. ${ }^{54}$

The Roberts Court has been less deferential than the New Deal Court. It has decided two cases implicating the role of the securities laws in the administrative state, and in both cases, the Court rejected the government's position. These results would suggest skepticism toward the government's arguments. When one probes beyond the results, however, the real skepticism would appear to be toward the Court's prior precedents. In these cases, the Roberts Court appears to be grappling more with the case law that it has inherited from earlier Courts rather than challenging the government's expertise.

\section{A. Antitrust v. Securities Regulation}

The Supreme Court has struggled to reconcile the antitrust and securities laws. The antitrust laws are premised on the benefits that free competition brings to the economy: lower price, and greater choice, both of which are presumed to enhance consumer welfare. The securities laws, like most regulatory schemes, create barriers to entry that invite anticompetitive behavior. The SEC's tolerance of price fixing of commissions by broker-dealers for the first forty years of its existence is the most notorious example. ${ }^{55}$

The Court has rarely waded into the conflict between these two regulatory regimes and it has struggled when it has done so. The Court's struggles can be traced to a bad start by the Warren Court in Silver v. New York Stock Exchange. ${ }^{56}$ Silver was a broker-dealer, not a member

\footnotetext{
${ }^{53}$ See Pritchard \& Thompson, supra note 1 , at

${ }^{54}$ See E. Thomas Sullivan \& Robert B. Thompson, The Supreme Court and Private Law: The Vanishing Importance of Securities and Antitrust, 53 Emory L.J. 1571, 1579-86 (2004) (describing the Supreme Court's expansive holding in all but a handful of securities cases until 1973).

${ }^{55}$ See Gordon v. New York Stock Exchange, 422 U.S. 659 (1975).

56373 U.S. 341 (1963).
} 
of the New York Stock Exchange, who had his wire connection to a number of other brokerdealers terminated at the order of the New York Stock Exchange. ${ }^{57}$ Silver brought suit against the exchange, alleging that the termination of his connection was a collective refusal to deal that violated the Sherman Act. The Second Circuit held that the claim was barred because the exchange was exercising powers it held under the Exchange Act, which had impliedly repealed the antitrust laws with respect to those powers. ${ }^{58}$

The Supreme Court reversed, concluding that the Second Circuit had erred in excluding the antitrust laws altogether: "the proper approach ... is an analysis which reconciles the operation of both statutory schemes with one another rather than holding one completely ousted." ${ }^{59}$ The Court then went on to reconcile the two schemes by turning to ... due process? The Court held that the antitrust laws had been violated because the exchange had not afforded the broker-dealer notice and hearing before terminating his wire connection. ${ }^{60}$ The Court's injection of due process into antitrust was summarily dismantled by Justice Stewart in his dissent, ${ }^{61}$ and has baffled both securities and antitrust lawyers since it was handed down.

The Court has not overruled Silver, but the Burger Court worked hard to narrow its reach. In two cases decided the same day in 1975, the Court rejected antitrust claims against participants in the securities industry. Notably, in both cases the United States and the SEC, as amici, supported opposing sides. The first, United States v. National Association of Securities

\footnotetext{
${ }^{57}$ Silver, 373 U.S. at 344.

58302 F.2d 714 (1963).

${ }^{59}$ Silver, 373 U.S at 357.

${ }^{60}$ Silver, 373 U.S at 361-362.

${ }^{61}$ Silver, 373 U.S at 367, 370 (Stewart, J., dissenting) ("Whether there has been a violation of the antitrust laws depends not at all upon whether or not the defendants' conduct was arbitrary.").
} 


\section{Securities Law in the Roberts Court}

Dealers, ("NASD") involved resale practices in the mutual fund industry. ${ }^{62}$ The second, Gordon v. New York Stock Exchange, involved the fixed brokerage commissions mentioned above. ${ }^{63}$

In both cases, the Court concluded that the practices at issue were immune from antitrust scrutiny, but only after painstaking review of the SEC's involvement in the challenged practice. In the NASD case, Justice Powell, writing for the Court, reviewed the SEC's involvement in mutual fund pricing under the Investment Company Act at length before concluding "maintenance of an antitrust action for activities so directly related to the SEC's responsibilities poses a substantial danger that [the mutual fund managers] would be subject to duplicative and inconsistent standards." ${ }^{64}$ In Gordon Justice Blackmun conducted an equivalent review of the SEC's involvement in brokerage commissions before concluding that Congress intended "to leave the supervision of the fixing of reasonable rates of commission to the SEC." 65 These decisions purported to leave intact Silver's governing principle that "[r]epeal is to be regarded as implied only if necessary to make Securities Exchange Act work, an even then only to the minimum extent necessary." ${ }^{66}$ Silver survived because the Court concluded that the minimum repeal "necessary" was quite.

The Court's unwillingness to overrule Silver left the door open for the claim in Credit Suisse Securities (USA) LLC v. Billing. ${ }^{67}$ This case arose out of the "laddering" scandals of 20012002, in which it was alleged that underwriters, in exchange for allocations of shares in "hot" initial public offerings, extracted promises from institutional investors to purchase securities in

\footnotetext{
62422 U.S. 694 (1975).

${ }^{63} 422$ U.S. 659 (1975).

${ }^{64}$ NASD, 422 U.S. at 735.

${ }^{65}$ Gordon, 422 U.S. at 691.

${ }^{66}$ Silver, 373 U.S. at 357.

${ }^{67} 551$ U.S. 264 (2007).
} 


\section{Securities Law in the Roberts Court}

the secondary market at inflated prices and/or with inflated commissions. ${ }^{68}$ The twist in Credit

Suisse was that at least some of the conduct alleged, if proven, violated the securities laws as well as the antitrust laws. ${ }^{69}$ In fact, a parallel securities class action was brought, alleging essentially the same facts, resulting in a substantial settlement. ${ }^{70}$ The plaintiffs in Credit Suisse reasoned that if the conduct violated both the antitrust and the securities laws, then there was no inconsistency between the two regimes, making no repeal of the antitrust laws necessary..

As in Gordon and NASD, the Justice Department's Antitrust Division and the SEC were on opposing sides in the lower courts. In those earlier cases, the Solicitor General authorized the SEC to file its own brief in the Supreme Court. In Credit Suisse, however, the Solicitor General attempted to cobble together a compromise position when the case reached the Supreme Court. He argued the case should be remanded to the district court to determine "whether respondents' allegations of prohibited conduct can, as a practical matter, be separated from conduct that is permitted by the regulatory scheme." ${ }^{71}$ That task would require the lower court to decide whether SEC-permitted and SEC-prohibited conduct are "inextricably intertwined."

Justice Breyer, writing for the Court, rejected both the plaintiffs' and Solicitor General's arguments. He discerned "only a fine, complex, detailed line separate[ing] activity that the SEC permits or encourages (for which [plaintiffs] must concede antitrust immunity) from activity that the SEC must (and inevitably will) forbid (and which, on [plaintiffs'] theory, should be open to antitrust attack.)"12 The Court worried that only a "securities expert" could locate this line,

\footnotetext{
${ }^{68}$ Credit Suisse, 551 U.S. at 269-270.

${ }^{69}$ Credit Suisse, 551 U.S. at 278-279.

${ }^{70}$ In re IPO Litigation, Stipulation and Agreement of Settlement (Civ. Action NO. 21 MC 92 (SAS); (Oct. 5, 2009 S.D.N.Y.) (approving $\$ 586$ million settlement).

${ }^{71}$ Credit Suisse, 551 U.S. at 284 (quoting Brief for United States as Amicus Curiae 9).

${ }^{72}$ Credit Suisse, 551 U.S. at 279.
} 


\section{Securities Law in the Roberts Court}

and even then, the SEC might shift it by deciding that previously forbidden conduct was now permissible. $^{73}$ Moreover, Breyer worried that "nuanced nature of the evidentiary evaluations necessary to separate the permissible from the impermissible" would lead to inconsistent verdicts in the hands of "different nonexpert judges and different nonexpert juries." ${ }^{74}$ The unpredictability of such an arrangement for market participants is obvious. Rather than disrupting the scheme of securities regulation, the Court concluded that antitrust claims should be excluded in their entirety. Silver is not explicitly overruled in Credit Suisse, but Credit Suisse clearly steps back from Silver's inventive effort to preserve a role for the antitrust laws. In Credit Suisse Breyer leaves little doubt that Silver need not be taken seriously. Securities regulation is sufficiently pervasive that antitrust claims ordinarily will be barred.

Justice Thomas dissented, pointing to the savings clause found in the Exchange Act, which preserves "any and all" "rights and remedies." ${ }^{75}$ For Thomas, "[w]hen Congress wants to preserve all other remedies, using the word 'all' is sufficient." ${ }^{\prime 76}$ If adopted, Thomas's position would open the door to a myriad of antitrust claims challenging practices sanctioned by the securities laws. Literalism of this sort was put forward by Scalia in Merck and also rejected by the majority. The results in Credit Suisse and Merck suggest that textualism has a limited following on the Court.

The general theme of the majority opinion in Credit Suisse is judicial modesty; the Court lacks confidence in the ability of judges to understand the complexity of the securities markets. This judicial modesty, however, does not translate in judicial deference to the executive branch.

\footnotetext{
${ }^{73}$ Credit Suisse, 551 U.S. at 280.

${ }^{74}$ Credit Suisse, 551 U.S. at 281.

${ }^{75}$ Securities Exchange Act $\S 28(a) ; 15$ U.S.C. 78bb(a).

${ }^{76}$ Credit Suisse, 551 U.S. at 287, 289 (Thomas, J., dissenting).
} 


\section{Securities Law in the Roberts Court}

The Court was unimpressed with the Solicitor General's effort at compromise; his "inextricably intertwined" principle failed to address the line-drawing difficulties that the Court had found. The Court was unwilling to defer to the government's effort to push it (and lower courts) into resolving complicated disputes over competing regulatory paradigms.

\section{B. Separation of Powers}

The Roberts' Court other foray into the intersection of administrative law and securities law - Free Enterprise Fund v. Public Company Accounting Oversight Board"7 ("PCAOB") - is notable for two reasons. The first is that it is the only opinion of the nine securities law cases authored by the Chief Justice. The second is that it has almost nothing to do with the securities laws: Neither the majority nor the dissenters grapples with the decision's implications for the regulation of accounting.

PCAOB nominally involves the Sarbanes-Oxley Act, but it is mainly a constitutional separation of powers case. At issue was the provision of that law making PCAOB board members removable only by the SEC, and then only "for good cause shown." ${ }^{78}$ This provision was challenged as inconsistent with separation of powers doctrine because it deprived the President of meaningful oversight over officers exercising executive authority. The Chief Justice, for the majority, wrote a lengthy opinion surveying the Court's prior decisions involving "for cause" restrictions, which were upheld by the New Deal Court in Humphrey's Executor. ${ }^{79}$ The tenor of his discussion of those prior precedents is at best grudging, but he eventually comes to the conclusion that some restrictions on the President's removal authority are permissible. The

\footnotetext{
77130 S. Ct. 3138 (2010).

7815 U.S.C. $\S 7211(\mathrm{e})(6)$. A second issue was raised in the case regarding the appointment of the PCAOB members by the SEC, but the Court rejected the argument summarily. See PCAOB, $130 \mathrm{~S}$. Ct. at

${ }^{79}$ Humphrey's Executor v. United States, 295 U.S. 602 (1935).
} 


\section{Securities Law in the Roberts Court}

double "for cause" removal provision at issue in PCAOB, however, was too much. ${ }^{80}$ In a similarly lengthy opinion (with Appendix!), Justice Breyer, joined by Justices Stevens, Ginsburg, and Sotomayor, concluded that it was not. ${ }^{81}$

For the average securities lawyer, the only thing of interest in the opinions is that the Court found that the unconstitutional "for cause" provision was severable from the remainder of the Sarbanes-Oxley Act. ${ }^{82}$ The question of severability was the only topic that created any drama; the Court's holding meant that the decision was largely a non-event for the practice of securities law because the Sarbanes-Oxley Act was left generally intact. Whether the members of the PCAOB are removable or not is not likely to make much of a difference for the day-to-day practice of accounting regulation.

For the scholar of securities law, the opinion is notable both for what it includes and what it omits. The notable inclusion is the Court's assumption that the members of the SEC are removable only for cause, despite the lack of a textual basis for that conclusion. ${ }^{83}$ As Justice Breyer points out in his dissent, the majority stretches to create a constitutional question by reading a for cause provision for the removal of SEC Commissioners into the Exchange Act. ${ }^{84}$ If the Court had instead read the Exchange Act to allow for at will removal of SEC Commissioners

\footnotetext{
${ }^{80}$ PCAOB, $130 \mathrm{~S}$. Ct. at 3164 ("While we have sustained in certain cases limits on the President's removal power, the Act before us imposes a new type of restriction-two levels of protection from removal for those who nonetheless exercise significant executive power. Congress cannot limit the President's authority in this way.").

${ }^{81}$ PCAOB, $130 \mathrm{~S}$. Ct. at 3184 (Breyer, J., dissenting) ("in my view, the Court's decision is wrong-very wrong.").

${ }^{82}$ PCAOB, 130 S. Ct. at 3161-3162.

${ }^{83}$ PCAOB, $130 \mathrm{~S}$. Ct. at 3148-3149 ("The parties agree that the Commissioners cannot themselves be removed by the President except under the Humphrey's Executor standard of "inefficiency, neglect of duty, or malfeasance in office," 295 U.S., at 620, (internal quotation marks omitted); see Brief for Petitioners 31; Brief for United States 43; Brief for Respondent Public Company Accounting Oversight Board 31 (hereinafter PCAOB Brief); Tr. of Oral Arg. 47, and we decide the case with that understanding.").

${ }^{84}$ PCAOB, 130 S. Ct. at 3182-3183 (Breyer, J., dissenting).
} 


\section{Securities Law in the Roberts Court}

by the President, the novel constitutional question of double for cause removal could have been avoided. ${ }^{85}$

Why did the Court depart from its usual practice of construing statutes to avoid constitutional questions? If one reads the majority's opinion, the most reasonable conclusion to draw from the arguments offered there is that restrictions on the President's power to remove the SEC commissioners violate the separation of powers. The holding, however, targets the new kid in town, the PCAOB. The SEC's status in the pantheon of regulatory agencies is apparently so secure that it is unthinkable for the Court to question its independence from the executive, notwithstanding the absence of a textual basis in the Exchange Act for a "for cause" provision.

The notable omission from the opinion is any discussion of Congress's goals in insulating the members of the PCAOB from removal. The omission is telling. Congress was not likely concerned about presidential interference with the Board's operations; rather, the real threat was from Congress itself. Politics abhors a vacuum of governmental authority. By insulating the SEC from the President's removal authority, Congress made the SEC not independent, but rather, dependent on Congress. ${ }^{86}$ That dependence allowed Congress to strongarm the SEC on the question of auditor independence. ${ }^{87}$ When Arthur Andersen collapsed in the wake of the Enron scandal, the auditing firm's substantial revenue stream from consulting for Enron was diagnosed as the principal cause. Faced with a flurry of embarrassing headlines, Congress quickly got religion on the question of auditor independence. That newfound fervor found its

\footnotetext{
${ }^{85}$ PCAOB, 130 S. Ct. at 3184 (Breyer, J., dissenting).

${ }^{86}$ I delve into this point in The SEC at 70: Time for Retirement? 80 Notre Dame L. Rev. 1073 (2005)

87 Interview with Arthur Levitt, Frontline (March 12, 2002), transcript available at http://www.pbs.org/wgbh/pages/frontline/shows/regulation/interviews/levitt.html.
} 


\section{Securities Law in the Roberts Court}

expression in the independence conferred on the PCAOB, which was insulated both from the

President and Congress in the hope that it would protect accounting regulation from political interference. None of this history is covered in the Court's opinion, which blinks reality by asserting "that one branch's handicap is another's strength." ${ }^{88}$ This point applies to the "for cause" removal requirement for the SEC, but has much less force when applied to the PCAOB. Moreover, the dissent fails to challenge the majority on its skewed understanding of the balance of power between Congress and the President. This omission by both sides of any discussion of the rationale for the PCAOB's independence might be taken as further evidence of the gap between the Court's securities jurisprudence and the political economy of securities regulation. In fairness to the Court, however, it is difficult to sound judicial while discussing interest group pressures on Congress and their influence on accounting policy. Do the justices really want to introduce the question of campaign contributions into separation of powers jurisprudence? That said, the Court's decision restores some of the influence that Congress previously held over the accounting profession. Any benefit to Presidential oversight from the Court's striking down the PCAOB's "for cause" provision seems de minimis by comparison.

\section{Securities Laws and the Administrative State}

Credit Suisse and $P C A O B$ reflect efforts by the Roberts Court to limit the effect of prior precedents that it considers misguided. In Credit Suisse, it is the Warren Court's confused Silver decision, which conflates antitrust and due process. In PCAOB, it is the New Deal Court's decision in Humphrey's Executor, animated by the belief in the need to insulate expert agencies from political interference. Both lines of precedent have implications that go well beyond the

\footnotetext{
${ }^{88}$ PCAOB, 130 S. Ct. at 3156.
} 
administration of the securities laws. The opinions in Credit Suisse and PCAOB are directed at those debates, paying scant attention to the substance of the securities laws.

\section{The Class Action Menace?}

The Roberts Court has decided substantive issues in four securities class actions during the Chief Justice's first five years. On the nominal scorecard, plaintiffs have won one of those cases, and the defendants the other three. A closer look at those decisions, however, suggests more balance; informed observers would put the tally closer to two and two. ${ }^{89}$ Plaintiffs have been rebuffed when they attempted to expand the boundaries of private litigation, but the Roberts Court has also overturned lower court decisions that would have curtailed the existing availability of securities class actions.

\section{A. The Pleading Standard}

Tellabs, Inc. v. Makor Issues \& Rights, $L t d .^{90}$ is one of the Supreme Court's first efforts to grapple with the PSLRA. The decision interprets the PSLRA's "strong inference" standard for pleading scienter-the defendants' state of mind-in Rule $10 \mathrm{~b}-5$ cases. ${ }^{91}$ After the enactment of the PSLRA, the different circuits took divergent approaches in applying the strong inference standard. The Second Circuit relied on the legislative history and held that the PSLRA codified its pre-PSLRA pleading approach based on motive and opportunity and on recklessness. ${ }^{92}$ The

\footnotetext{
${ }^{89}$ If one were to include Dabit (defendant win) and Merck (plaintiff win) in this tally, the numbers would change to three to three.

501 U.S. 308 (2007).

${ }^{91}$ Exchange Act $\S 21 \mathrm{D}(\mathrm{b})(2)$.

92 Novak v. Kasaks, 216 F.3d 300, 311 (2000). The PSLRA's strong inference scienter provision was modeled after the standard applied in the Second Circuit prior to the PSLRA, which was generally regarded as the most stringent at the time. See S. Rep. No. 104-98, at 15 (1993), reprinted in 1995-96 U.S.C.C.A.N. 679, 694. Prior to the PSLRA, the Second Circuit had held that plaintiffs could meet the scienter standard in one of two ways. First, plaintiffs
} 


\title{
Securities Law in the Roberts Court
}

Ninth Circuit also relied on the PSLRA's legislative history, but concluded that the statute raised

\author{
the standard above that of the Second Circuit. ${ }^{93}$ Under the higher Ninth Circuit pleading
}

standard, plaintiffs had to plead, "at a minimum, particular facts giving rise to a strong

inference of deliberate or conscious recklessness." ${ }^{94}$ Most circuits, however, took a middle

course in interpreting the strong inference standard, concluding that motive and opportunity

allegations might suffice to support a strong inference of scienter, but courts would need to

evaluate such allegations on a "case-by-case" basis. ${ }^{95}$

could plead that the defendants had the motive to commit fraud and the opportunity to do so. Goldman v. Belden, 754 F.2d 1059 (2d Cir. 1985). Although simplistic allegations of motive that could apply generally, such as keeping one's job, see In re Crystal Brands Sec. Litig., 862 F. Supp. 745, 749 (D. Conn. 1994), were insufficient to meet the standard, other allegations of specific financial gain from a transaction were sufficient to state a claim-such as evidence of abnormal levels of insider trading. See Goldman v. Belden, 754 F.2d 1059, 1070 (2d Cir. 1985) (holding that allegations that defendants bullish statements to market were connected to significant stock sales met motive and opportunity test). Second, plaintiffs could meet the standard with circumstantial evidence of either recklessness or conscious behavior. See San Leandro Emergency Med. Group Profit Sharing Plan v. Philip Morris Co., 75 F.3d 801 (2d Cir. 1996) (requiring plaintiffs seeking to meet recklessness standard to provide higher level of detail than that required under motive and opportunity test). Generally, this standard required plaintiffs to plead contemporaneous facts, conditions, or statements to show that the defendants knew or should have known that the alleged misstatement was misleading when made. See Shields v. Citytrust Bancorp, 25 F.3d 1124, 1129 (2d. Cir. 1994) (rejecting allegations of fraud where plaintiffs failed to contrast public disclosure with contemporaneous internal document or data).

The Second Circuit has refined its explication of its scienter standard post-PSLRA. Now, rather than a twoprong test, the Second Circuit has set forth a list of the general types of allegations that will meet the heightened pleading standard for scienter. Synthesizing its own case law on the pleading standard, the Second Circuit held that plaintiffs can plead a strong inference of fraudulent intent by including sufficient allegations that the defendants: received concrete, personal benefits from the alleged fraud; participated in deliberately illegal behavior; knew or had access to facts "suggesting" that the public statements were inaccurate; or "failed to check information they had a duty to monitor." See id. at 311. This refined standard, of course, still leaves room for pleading based on motive and opportunity.

${ }_{93}^{93}$ See In re Silicon Graphics Inc. Sec. Litig., 183 F.3d 970, 974 (9th Cir. 1999).

${ }^{94} / d$.

${ }^{95}$ Greebel v. FTP Software, Inc., 194 F.3d 185 (1st Cir. 1999); Ottman v. Hanger Orthopedic Group, Inc. 353 F.3d 338 (4th Cir. 2003); Nathenson v. Zonagen, Inc., 267 F.3d 400 (5th Cir. 2001); In re Comshare, Inc. Sec. Litig., 183 F.3d 542 (6th Cir. 1999); Makor Issues \& Rights, Ltd. v. Tellabs, Inc., 437 F.3d 588 (7th Cir. 2006); Fla. State Bd. of Admin v. GreenTree Fin. Corp., 270 F.3d 645 (8th Cir. 2001); In re Silicon Graphics, 183 F.3d 970 (9th Cir. 1999); City of Philadelphia v. Fleming Cos., 264 F.3d 1245 (10th Cir. 2001); Bryant v. Avado Brands, Inc., 187 F.3d 1271 (11th Cir. 1999).

The choice of scienter standard has important consequences: the Ninth Circuit, in adopting the most stringent standard post-PSLRA, also substantially increased its dismissal rate. An earlier study found that Ninth Circuit courts dismissed cases at a $63 \%$ rate, while Second Circuit courts dismissed only $36 \%$. See A.C. Pritchard \& Hillary Sale, 


\section{Securities Law in the Roberts Court}

When the Supreme Court finally entered the fray over the interpretation of the strong inference standard in Tellabs, it did not resolve this longstanding split among the circuits over the application of the standard, which most observers had been expecting. Instead, it addressed a collateral, but related, issue on which the circuits also had split: In considering whether the facts alleged by the plaintiff meet the strong inference standard, how should courts assess the allegations in the complaint and the different possible inferences that might be drawn from those allegations with respect to scienter? In particular, should a court consider competing inferences arising from those facts?

Prior to the Supreme Court's Tellabs opinion, the circuit courts split into three groups in assessing competing inferences. The First, Fourth, Sixth, and Ninth Circuits adopted a "preponderance" standard. ${ }^{96}$ The preponderance standard requires the inference that the defendants had the requisite scienter be the most plausible when compared with competing inferences that the defendants did not have scienter. Combined with the Ninth Circuit's higher deliberate or conscious recklessness scienter standard, this standard made it easier for defendants to obtain dismissal in the Ninth Circuit. The Second, Eighth, Tenth, and Eleventh Circuits required that the inference that the defendants acted with the requisite scienter must be at least equally plausible with competing inferences. ${ }^{97}$ Finally, the Third and Seventh Circuits followed the most plaintiff-friendly approach, adopting the "reasonableness" standard that did

What Counts As Fraud? An Empirical Study of Motions to dismiss Under the Private Securities Litigation Reform Act, 2 J. Emp. Leg. Stud. 125 (2005).

${ }_{96}$ In re Credit Suiss First Boston Corp., 431 F.3d 36 (1st Cir. 2005); Ottman v. Hanger Orthopedic Group, Inc., 353 F.3d 338 (4th Cir. 2003); Helwig v. Vencor, Inc., 251 F.3d 540 (6th Cir. 2001); Gompper v. VISX, Inc., 298 F.3d 893 (9th Cir. 2002).

${ }_{97}$ Acito v. IMCERA Group, Inc., 47 F.3d 47 (2d Cir. 1995); Rosenzweig v. Azurix Corp., 332 F.3d 854 (5th Cir. 2003); Fla. State Bd. Of Admin v. Gree Tree Fin. Corp., 270 F.3d 645 (8th Cir. 2001); Pirraglia v. Novell, Inc., 339 F.3d 1182 (10th Cir. 2003); Garfield v. NDC Health Corp., 466 F.3d 1255 (11th Cir. 2006). 


\section{Securities Law in the Roberts Court}

not require any assessment of competing inferences, looking only at the plausibility of the plaintiff's allegations. ${ }^{98}$ Under the Seventh Circuit's reasonableness standard as set forth in Makor Issues \& Rights, Ltd. v. Tellabs, Inc. (the lower court opinion before the Supreme Court in Tellabs), a complaint should survive "if it alleges facts from which, if true, a reasonable person could infer that the defendant acted with the required intent." 99

The Seventh Circuit standard faced an uphill fight in the Supreme Court. The government's amicus brief in Tellabs argues that the Seventh Circuit's reasonableness standard would have made Congress's effort in enacting the PSLRA scienter standard toothless, as it would mean reverting to pre-PSLRA standards under Rule 9(b) of the Federal Rules of Civil Procedure. ${ }^{100}$ The government's brief is notable in that it sides with the defendants, an unusual occurrence in its amicus practice. ${ }^{101}$ The SEC has historically sided with the plaintiffs' bar, ${ }^{102}$ and even minor deviations from that role bring a firestorm of criticism from the plaintiffs' bar and its allies. ${ }^{103}$ The SEC's support for the plaintiffs' bar in part reflects its own institutional interests. The agency favors broad interpretations of its governing statutes; a narrow interpretation of $\S 10(b)$ could reduce the SEC's enforcement discretion, but the agency commonly sides with the plaintiffs' bar even on issues that relate purely to the terms of the

\footnotetext{
98 In re Suprema Specialties, Inc. Sec. Litig., 438 F.3d 256 (3rd Cir. 2006).

${ }^{99} 437$ F.3d 588, (7th Cir. 2006).

100 Brief for the United States as Amicus Curiae Supporting Petitioners, Tellabs, Inc. v. Makor Issues \& Rights, Ltd., No. 06-484, 2007 WL 460606, at *23 (arguing that "the court of appeals' standard appears to be equivalent to the standard that it (and some other courts of appeals) had applied before the enactment of the Reform Act, under which a complaint was sufficient if the plaintiff pleaded facts that supported at least a reasonable inference of state of mind.").

${ }^{101}$ See id. at *26 (arguing that "if the alleged facts give rise to two seemingly equally strong competing inferences, a court must conclude that the inference of scienter is not itself strong.") (citations and quotation marks omitted).

102 See Pritchard, supra note at 923 (quoting Lewis Powell complaining that "SEC usually favors all $\pi$. I can't recall a case in which this was not so.").

103 See, e.g., Stephen Labaton, S.E.C. Seeks to Curtail Investor Suits, N.Y. Times, Feb. 13, 2007, at C1; Stephen Labaton, Is the S.E.C. Changing Course? N.Y. Times, March 1, 2007, at C1. Labaton is the son of a prominent plaintiffs' lawyer, Ed Labaton.
} 


\section{Securities Law in the Roberts Court}

implied Rule 10b-5 cause of action. So here the Court faced the unusual scenario of the government siding with the defendants.

The Court was unmoved by this unusual alignment in interpreting the PSLRA's "strong inference" language. Ginsberg characterized her role as framing "a workable construction of the 'strong inference' standard, a reading geared to the PSLRA's twin goals: to curb frivolous, lawyer-driven litigation, while preserving investors' ability to recover on meritorious claims." ${ }^{104}$ Having framed the inquiry in this way, it is no surprise that Ginsberg settled on the intermediate position. She rejected the reasonableness standard adopted by the lower court, instead requiring a comparative inquiry: "A complaint will survive, we hold, only if a reasonable person would deem the inference of scienter cogent and at least as compelling as any opposing inference one could draw from the facts alleged."105 That conclusion was compelled by Congress's use of the word "strong." According to Ginsberg, "[t]he strength of an inference cannot be decided in a vacuum. The inquiry is inherently comparative: How likely is it that one conclusion, as compared to others, follows from the underlying facts?"106 At a minimum, therefore, the Court felt compelled to choose the intermediate "equal inference" standard, rejecting the "reasonableness" standard. Ties go to the plaintiff, but the plaintiff, as the master of the complaint, must show that the inference of fraudulent intent is at least as likely as an innocent one.

In so doing, the Court also rejected the "preponderance" standard favored by the defendants and the government, as well as garnering the support of Justices Scalia and Alito in

\footnotetext{
104 Tellabs, 551 U.S. at 322.

105 Tellabs, 551 U.S. at 324.

${ }^{106}$ Tellabs, 551 U.S. at 323.
} 


\section{Securities Law in the Roberts Court}

their concurrences. ${ }^{107}$ Scalia gets points for his colorful illustration of his disagreement with

Ginsberg:

If a jade falcon were stolen from a room to which only $A$ and $B$ had access, could it possibly be said there was a "strong inference" that B was the thief? I think not, and I therefore think that the Court's test must fail. In my view, the test should be whether the inference of scienter (if any) is more plausible than the inference of innocence. ${ }^{108}$

This provoked the predictable exchange between Scalia and Ginsberg over the analogy, and more fundamentally, the "meaning" of the word strong. ${ }^{109}$ Scalia also engaged in a familiar debate with both the majority and Stevens (who dissented) over the appropriate approach to statutory interpretation generally, complete with the standard Scalia complaint about the use of legislative history. ${ }^{110}$ Scalia was particularly provoked by Stevens' free-wheeling approach to statutory interpretation. For Scalia, such discretion is "conferred upon administrative agencies, which need not adopt what courts would consider the interpretation most faithful to the text of the statute, but may choose some other interpretation, so long as it is within the bounds of the reasonable."111 Courts "must apply judgment, to be sure. But judgment is not discretion."112

Stevens shot back that "[t]he meaning of a statute can only be determined on a case-bycase basis and will, in each case, turn differently on the clarity of the statutory language, its context, and the intent of its drafters. ${ }^{113}$ Stevens preferred a "probable cause" standard because "it is a concept that is familiar to judges" and "[a]s a matter of normal English usage, its

\footnotetext{
${ }^{107}$ Tellabs, 551 U.S. at 329 (Scalia, J., concurring); 551 U.S. at 331 (Alito, J., concurring).

108 Tellabs, 551 U.S. at 329 (Scalia, J., concurring).

${ }^{109}$ Tellabs, 551 U.S. at 331-332 (Scalia, J., concurring).

110 Tellabs, 551 U.S. at 329 (Scalia, J., concurring) ("Even if I agreed with the Court's interpretation of "strong inference," I would not join the Court's opinion because of its frequent indulgence in the last remaining legal fiction of the West: that the report of a single committee of a single House expresses the will of Congress.").

${ }^{111}$ Tellabs, 551 U.S. at 332 (Scalia, J., concurring).

${ }^{112}$ Id.

${ }^{113}$ Tellabs, 551 U.S. at 335, 336 n.1 (Stevens, J., dissenting).
} 


\section{Securities Law in the Roberts Court}

meaning is roughly the same as 'strong inference'."114 It is unclear who normally uses "probable cause" at all, other than criminal defense lawyers and prosecutors. Stevens, however, made no pretense that this is what Congress intended in adopting the "strong inference" phrasing. Suffice to say, none of the participants in this intramural debate persuaded the others.

In fairness to the justices, it is not altogether clear that much of anything was at stake once the implausible "reasonableness" standard was rejected. Is there much difference between the equal inference and preponderance standards? In theory, the two differ only when the competing inferences are tied. The equal inference standard awards ties to the plaintiffs, leading to a rejection of the defendants' motion to dismiss on scienter grounds; the preponderance standard awards ties to the defendants, leading to a dismissal. As Justice Scalia noted in his concurrence, the difference between the equal inference and preponderance standards is likely to be determinative in only a small fraction of cases: "How often is it that inferences are precisely in equipoise?"115

Given the limited change to the law effected by Tellabs in most circuits, would it make any difference to outcomes? It turns out that it does. Steve Choi and I, in a study comparing motions to dismiss based on the pleading standard before and after Tellabs, found that dismissals declined sharply in the Ninth Circuit after the decision, and that the incidence of nuisance settlements climbed in that circuit. ${ }^{116}$ The justices were debating amongst themselves

\footnotetext{
${ }^{114}$ Tellabs, 551 U.S. at 336 (Stevens, J., dissenting).

115 Tellabs, 551 U.S. at 331 (Scalia, J., concurring).

116 See Stephen J. Choi \& A.C. Pritchard, The Supreme Court's Impact on Securities Class Actions: An Empirical Assessment of Tellabs, (Working Paper, 2010).
} 


\section{Securities Law in the Roberts Court}

the proper approach to statutory interpretation; their somewhat academic debate had real consequences for litigants. That observation, however, is one made only in hindsight.

\section{B. Mutual Fund Litigation}

A less prominent feature of the Court's securities jurisprudence is the regulation of mutual funds under the Investment Company Act of $1940 .^{117}$ Jones v. Harris Associates $L P^{118}$ came to the Court from the Seventh Circuit. The dispute over the case in the Seventh Circuit is probably the most interesting aspect of the case. The plaintiffs' claim in Jones was that the investment adviser to the mutual fund in question collected excessive fees for its management services, thereby breaching its "fiduciary duty with respect to the receipt of compensation for services." multifactor analysis first adopted by the Second Circuit in Gartenberg v. Merrill Lynch Asset Management, Inc. ${ }^{120}$ Judge Frank Easterbrook wrote the decision for the Seventh Circuit affirming the grant of summary judgment, but he departed drastically from the rationale applied by the lower court. ${ }^{121}$ In Easterbrook's view, the fiduciary duty standard of the Investment Company Act was a limited one: "A fiduciary must make full disclosure and play no tricks but is not subject to a cap on compensation."122 Easterbrook's support for this narrow definition of fiduciary duty: the forces of competition, driven by sophisticated investors, imposed substantial pressure to keep advisory fees low, so judicial scrutiny would add little. ${ }^{123}$ The free market ethos underlying this argument brought a rebuke from, of all people, Judge

\footnotetext{
11754 Stat. 789,15 U.S.C. $\S 80 a-1$ et seq.

118130 S. Ct. 1418 (2010).

11915 U.S.C. § 80a-35(b).

${ }^{120} 694$ F.2d 923 ( $\left.2^{\text {nd }} C i r .1982\right)$

${ }^{121} 527$ F.3d 627 (2008).

122527 F.3d at 632.

${ }^{123} 527$ F.3d at 633-634.
} 


\section{Securities Law in the Roberts Court}

Richard Posner, who critiqued Easterbrook's "economic analysis" as being "ripe for reexamination."124 Posner's faith in markets has apparently been shaken by the late financial crisis. $^{125}$

Easterbrook's aggressive position created a conflict with other circuits, necessitating Supreme Court review, but his position got little support there. Both the defendant and the government declined to endorse it, instead endorsing the Gartenberg standard. ${ }^{126}$ The Court declined to take a position on the Easterbrook/Posner debate: "The debate between the Seventh Circuit panel and the dissent from the denial of rehearing regarding today's mutual fund market is a matter for Congress, not the courts."127 Instead, the Supreme Court fell into line with the overwhelming weight of lower court authority, endorsing the Gartenberg standard as a matter of statutory interpretation.

Justice Alito, writing for the Court, said that Congress meant to adopt the Court's standard from Pepper v. Litton: "The essence of the test is whether or not under all the circumstances the transaction carries the earmarks of an arm's length bargain." ${ }^{128}$ Oddly, Alito offers no reason at all for this conclusion. ${ }^{129}$ It appears to be the correct interpretation of the statute because it is the Court's general interpretation of fiduciary duty. If Congress wants to deviate from the judicial standard, it will have to be clear about it. Pepper is the standard that the justices know.

\footnotetext{
${ }^{124} 537$ F.3d 728, 730 (Posner, J., dissenting from the denial of rehearing en banc).

125 Richard A. Posner, The Crisis of Capitalism (2010); Richard A. Posner, A Failure of Capitalism: The Crisis of '08 and the Descent into Depression (2009).

126 Jones, $130 \mathrm{~S}$. Ct. at 1425.

127 Jones, $130 \mathrm{~S}$. Ct. at 1430-1431.

128 Jones, 130 S. Ct. at 1427 (quoting Pepper v. Litton, 308 U.S. 295 (1939); emphasis supplied by Jones Court).

129 Jones, $130 \mathrm{~S}$. Ct. at 1427 ("We believe that this formulation expresses the meaning of the phrase 'fiduciary duty' in $\S 36($ b) [of the Investment Company Act]").
} 


\section{Securities Law in the Roberts Court}

The Court's endorsement of the Gartenberg standard appears grudging at best. Alito emphasized courts should be cautious in making comparisons between fees charged to mutual funds and institutional investors. ${ }^{130}$ He also noted that courts must defer to "the judgment of disinterested directors apprised of all relevant information" absent "additional evidence that the fee exceeds the arm's-length range."131 Alito closes with a caution that sounds much like the business judgment rule: "In reviewing compensation under $\S 36(\mathrm{~b})$, the Act does not require courts to engage in a precise calculation of fees representative of arm's-length bargaining. ... Congress' approach recognizes that courts are not well suited to make such precise calculations." ${ }^{132}$ The Court rejected the Seventh Circuit's interpretation that would have largely neutered the Investment Company Act's fiduciary duty standard, but its interpretation of the Gartenberg standard is so narrow that plaintiffs face huge obstacles to actually winning their claims. ${ }^{133}$

C. Scheme Liability

130 Jones, 130 S. Ct. at 1429 ("Even if the services provided and fees charged to an independent fund are relevant, courts should be mindful that the Act does not necessarily ensure fee parity between mutual funds and institutional clients contrary to petitioners' contentions.") .

131 Jones, $130 \mathrm{~S}$. Ct. at 1430.

132 Jones, $130 \mathrm{~S}$. Ct. at 1430 (citations omitted).

133 Justice Thomas, concurring, would have gone still further in distancing the Court from judicial ratemaking:

I concur in the Court's decision to affirm this approach based upon the Investment Company Act's text and our longstanding fiduciary duty precedents. But I would not say that in doing so we endorse the "Gartenberg standard." Whatever else might be said about today's decision, it does not countenance the free-ranging judicial "fairness" review of fees that Gartenberg could be read to authorize, see 694 F.2d, at 929-930, and that virtually all courts deciding § 36 (b) cases since Gartenberg (including the Court of Appeals in this case) have wisely eschewed in the post Gartenberg precedents we approve.

Jones, 130 S. Ct. at 1431 (Thomas, J., concurring). 


\section{Securities Law in the Roberts Court}

Stoneridge Investment Partners, LLC v. Scientific-Atlanta, Inc. ${ }^{134}$ is easily the most controversial of the Roberts Court's securities law decisions, provoking a (failed) attempt at a legislative override. Appropriately, the decision is a sequel to the Rehnquist Court's most controversial effort to curtail securities class actions - Central Bank of Denver v. First Interstate Bank of Denver ${ }^{135}$ - which provoked a partial legislative override of its own. Central Bank, like Stoneridge, was written by Justice Anthony Kennedy, and brief summary is needed to set the stage for Stoneridge. The issue presented in Central Bank was whether private civil liability under $\S 10(b)$ (the authorizing statute for Rule 10b-5) extends to aiders and abettors of the violation. The open ended nature of aiding and abetting liability worried Kennedy. In Central Bank, he warned that uncertainty over the scope of liability could induce secondary actors to settle "to avoid the expense and risk of going to trial." ${ }^{136}$ The risk of having to pay such settlements could cause professionals, such as accountants, to avoid newer and smaller companies, and "the increased costs incurred by professionals because of the litigation and settlement costs under $10 \mathrm{~b}-5$ may be passed on to their client companies, and in turn incurred by the company's investors, the intended beneficiaries of the statute."137

In an effort to increase Rule 10b-5's predictability, Kennedy's opinion adopted a twopart framework for addressing the scope of the private right of action under $\S 10(b)$. In the first step of the inquiry, Kennedy examined the text of $\S 10(b)$ to determine the scope of the conduct prohibited by the provision. He had little difficulty determining that the text of $\S 10$ (b) "prohibits only the making of a material misstatement (or omission) or the commission of a

\footnotetext{
${ }^{134} 552$ U.S. 148 (2008).

135511 U.S. 164 (1994).

${ }^{136}$ Central Bank, 511 U.S. at 189.

${ }^{137}$ Id.
} 


\section{Securities Law in the Roberts Court}

manipulative act."138 This settled the question for Kennedy: aiding and abetting was not prohibited by $\S 10(b)$.

Nonetheless, Kennedy set forth a second-step to the inquiry:

When the text of $\S 10(b)$ does not resolve a particular issue, we attempt to infer how the 1934 Congress would have addressed the issue had the $10 \mathrm{~b}-5$ action been included as an express provision in the 1934 Act. For that inquiry, we use the express causes of action in the securities Acts as the primary model for the $\S$ 10(b) action. The reason is evident: Had the $73 \mathrm{~d}$ Congress enacted a private $\S$ 10 (b) right of action, it likely would have designed it in a manner similar to the other private rights of action in the securities Acts ... . ${ }^{139}$

The plaintiffs' argument also failed under this second step, because the explicit causes of action afforded by Congress in the Securities Act and the Exchange Act were similarly silent on the question of aiding and abetting. Whether the question is resolved under the first or the second step of this inquiry has potentially significant consequences. When the Court interprets $\S 10(b)$, it is defining not only the limits of the private cause of action, but also the reach of the SEC'S authority. When it constructs the hypothetical cause of action in the second step, only the private cause of action is implicated.

In passing, Kennedy noted one additional problem with the plaintiffs' argument, which would have important consequences in Stoneridge: "Were we to allow the aiding and abetting action proposed in this case, the defendant could be liable without any showing that the plaintiff relied upon the aider and abettor's statements or actions."140 The Court left the door

\footnotetext{
${ }^{138}$ Central Bank, 511 U.S. at 177.

139 Id. at 178 (citations and internal quotation marks omitted). The Court has used the approach of looking to express causes of action to infer appropriate elements under the implied cause of action under Rule 10b-5 in other cases. Lampf, Pleva, Lipkind, Purpis \& Petigrow v. Gilbertson, 501 U.S. 350 (1991) (applying statute of limitations from Securities Act claims to Rule 10b-5 claim); Musick, Peeler \& Garrett v. Employers Ins. of Wausau, 508 U.S. 286, 297 (1993) (finding an implied right of contribution under Rule 10b-5 based on express right of contribution under explicit causes of action in the Exchange Act).

${ }^{140}$ Central Bank, 511 U.S. at 180.
} 


\section{Securities Law in the Roberts Court}

open for some liability for secondary participants, such as accountants, investment bankers, and lawyers, but only if they have exposed themselves to that risk by acting in a way that induces investor reliance. The bottom line after Central Bank is that a defendant must make a misstatement (or omission) on which a purchaser or seller of a security relies. Kennedy did not explain further the connection between reliance and the scope of Rule 10b-5; that issue would reemerge in Stoneridge.

The scope of a primary violation of Rule 10b-5 came back to the Court in Stoneridge. The Stoneridge plaintiffs attempted an end run around Central Bank: instead of alleging that the secondary defendants had made or participated in the making of a misstatement, the plaintiffs alleged that the secondary defendants were part of a "scheme to defraud," thus invoking a separate provision in Rule $10 \mathrm{~b}-5 .^{141}$

The scheme alleged by the plaintiffs in Stoneridge involved two suppliers of the cable company Charter Communications. The plaintiffs' complaint alleged that Charter committed a massive accounting fraud inflating its reported operating revenues and cash flow. The plaintiffs also named as defendants two equipment suppliers who provided cable set-top boxes to Charter, Scientific-Atlanta and Motorola. The plaintiffs alleged that Charter paid the suppliers $\$ 20$ extra for each set-top box in return for the supplier's agreement to make additional payments back to Charter in the form of advertising fees. Charter then capitalized the $\$ 20$ extra expense (shifting the accounting cost into the future) while treating the advertising fees as current income, artificially boosting Charter's current accounting revenues at the expense of future income. The suppliers had no direct role in preparing or disseminating the fraudulent

\footnotetext{
${ }^{141}$ Exchange Act Rule 10b-5(a).
} 


\section{Securities Law in the Roberts Court}

accounting information, nor did they approve Charter's financial statements. The plaintiffs

alleged, however, that the vendors facilitated Charter's deceptions by preparing false

documentation and backdating contracts. The district court granted the suppliers' motion to

dismiss, relying on Central Bank to hold that the vendors were not primary violators under Rule

10b-5. The court of appeals affirmed, concluding that the suppliers had not engaged in any

deception because they had made no misstatements, had no duty to disclose to Charter's

investors, and had not manipulated Charter's shares. ${ }^{142}$

As noted above, the SEC has consistently supported the expansion of private securities

class actions. ${ }^{143}$ So, too, in Stoneridge, with the majority of the commissioners voting to file a

brief siding with the plaintiffs. ${ }^{144}$ The agency was overruled, however, by the Solicitor General, who sided with the defendants. ${ }^{145}$ Here, the government's argument was essentially adopted in toto by the Court, so we have deference to the government, but not to the SEC.

The Supreme Court, by a vote of 5-3 (with Justice Breyer recused), affirmed. Justice Kennedy, writing for the Court, rejected the appellate court's holding that there was no

142 In re Charter Communications, Inc. Sec. Litig., 443 F.3d 987, 990-93 (8 ${ }^{\text {th }}$ Cir. 2006).

${ }^{143}$ Brief of the Securities and Exchange Commission, Amicus Curiae, In re Worldcom Securities Litigation, $2^{\text {nd }}$ Cir. 03-9350, available at http://www.sec.gov/litigation/briefs/wchevesi_amicus.htm\#summaflowry (last visited July 3, 3008) (noting SEC's support for FOTM presumption in Basic v. Levinson, and arguing for application of presumption to reports by securities analysts). See also Donald C. Langevoort, Basic at Twenty: Rethinking Fraud on the Market, 2009 Wisc. L. Rev. 151, 157 (2009) ("[T]he Basic opinion was for all practical purposes drafted by the SEC and the Office of the Solicitor General. Most all of the key arguments, analysis, quotes and citations that one finds in the Courts' holdings on both materiality and reliance come directly out of the amicus curiae brief filed on behalf of the SEC.").

${ }^{144}$ The vote was 3-2. See Paul Atkins, Just Say 'No" to the Trial Lawyers, Wall St. J., Oct. 9, 2007, at A17. Chairman Christopher Cox voted with the majority, despite having introduced the bill that in 1995 that would have reversed Basic. Joel Seligman, The Transformation of Wall Street 663-64 (3d Ed. 2003). The SEC had filed a brief in a Ninth Circuit case raising similar issues arguing that " " $t$ ] he reliance requirement is satisfied where a plaintiff relies on a material deception flowing from a defendant's deceptive act, even though the conduct of other participants in the fraudulent scheme may have been a subsequent link in the causal chain leading to the plaintiff's securities transaction." SEC Reply Br. at 12, Simpson v. AOL Time Warner, Inc., No. 04-55665 (Feb. 7, 2005) <http://www.sec.gov/litigation/briefs/homestore_020405.pdf> (last visited July 3, 2008).

${ }^{145}$ Brief for the United States as Amicus Curiae Supporting Affirmance (August 15, 2007). 


\section{Securities Law in the Roberts Court}

deception, noting that "[c]onduct itself can be deceptive." ${ }^{146}$ He instead hung the affirmance on the other doctrinal point from his Central Bank decision, the incompatibility of aiding and abetting liability with the "essential element" of reliance. ${ }^{147}$ He concluded that the presumptions of reliance from Affiliated Ute and Basic did not apply because the suppliers had no fiduciary duty to Charter's shareholders and the suppliers' statements were not disseminated to the public. In this case, investors relied on Charter for its financial statements, not the cable set-top box transactions underlying those financial statements. ${ }^{148}$ Why did Kennedy focus on defendants' conduct, rather than the plaintiffs, when assessing reliance? According to Kennedy, "reliance is tied to causation, leading to the inquiry whether [suppliers'] acts were immediate or remote to the injury. ${ }^{\prime 149}$ Kennedy was treating the reliance inquiry as a species of the tort concept of proximate cause.

As in Central Bank, Kennedy's principal concern was the specter of unlimited liability. According to Kennedy, "[w]ere this concept of reliance to be adopted, the implied cause of action would reach the whole marketplace in which the issuing company does business." ${ }^{150}$ If accepted, the plaintiff's theory threatened to inject the $\S 10(\mathrm{~b})$ cause of action into "the realm of ordinary business operations."151

Kennedy's rationale for limiting the concept of reliance could have more naturally been put into the "in connection with the purchase or sale of any security" language from $\S 10$ (b). Kennedy pointed to that language, but said that it did not control in this case because the "in

\footnotetext{
${ }^{146}$ Stoneridge, 558 U.S. at 158.

${ }^{147}$ Id.

${ }^{148}$ Id. (citing Affiliated Ute Citizens of Utah v. United States, 406 U.S. 128 (1972); Basic, Inc. v. Levenson, 485 U.S. 224 (1988).

${ }^{149}$ Stoneridge, 558 U.S.at 160.

150 Stoneridge, 558 U.S. at 160.

${ }^{151}$ Stoneridge, 558 U.S. at 161.
} 


\section{Securities Law in the Roberts Court}

connection with" requirement goes to the "statute's coverage rather than causation."152

Another reason for not putting the limit into that doctrinal category is that the Court had only

recently affirmed a very broad scope for that requirement. ${ }^{153}$ A more substantial reason is that

cabining Rule 10b-5 through the "in connection with the purchase or sale" requirement would

limit not only private plaintiffs, but potentially, the SEC, whose enforcement authority is limited

by the reach of the statute. Kennedy conceded that the SEC's enforcement authority might

reach commercial transactions like those between Charter and its suppliers, but he was reluctant to grant the same freedom to the plaintiffs' bar. ${ }^{154}$

Given the need to cabin the plaintiffs' bar, but maintain the SEC's discretion, the reliance requirement was an attractive tool. The reliance requirement, despite being an "essential element," does not flow the language of $\S 10(b)$, but is instead derived from the common law of deceit. ${ }^{155}$ More importantly for Kennedy's purposes, reliance does not apply in enforcement actions brought by the SEC or criminal prosecutions brought by the Justice Department. ${ }^{156}$ Putting the limit on secondary party liability in the reliance element allowed the Court to have its cake - unfettered government enforcement - and eat it too - constrain the scope of private actions.

The importance of the SEC's enforcement efforts had been reinforced by Congress's response to Central Bank. Rebuffing calls to restore aiding-and-abetting liability, Congress

\footnotetext{
152 Stoneridge, 558 U.S. at 160.

${ }^{153}$ See Merrill Lynch, Pierce, Fenner \& Smith v. Dabit, 547 U.S. 71 (2006); SEC v. Zandford, 535 U.S. 813 (2002).

154 Stoneridge, 552 U.S. at 161 ("Were the implied cause of action to be extended to the practices described here ... there would be a risk that the federal power would be used to invite litigation beyond the immediate sphere of securities litigation and in areas already governed by functioning and effective state-law guarantees.").

${ }^{155}$ See, e.g., List v. Fashion Park, Inc. 340 F.2d 457 (2d Cir. 1965).

156 Geman v. SEC, 334 F.3d 1183, 1191 (10 ${ }^{\text {th }}$ Cir. 2003) ("The SEC is not required to prove reliance or injury in enforcement cases."); United States v. Haddy, 134 F.3d 542, 549-51 (3d Cir. 1998) (government need not prove reliance in criminal case).
} 
instead gave that authority only to the SEC. ${ }^{157}$ Accepting the plaintiff's argument in Stoneridge, Kennedy reasoned, would thus "undermine Congress' determination that this class of defendants should be pursued by the SEC and not by private litigants." ${ }^{158}$ Kennedy's rationale for the need to constrain private litigants echoed and amplified the policy concerns he expressed in Central Bank. Expanding liability would undermine the US's international competitiveness and raise the cost of capital because companies would be reluctant to do business with American issuers. Issuers might list their shares elsewhere to avoid these burdens. $^{159}$

Looking at the question of reliance, it is difficult to extract any consistent guiding principle from the Court's decisions. Justice Stevens, dissenting in Stoneridge (as he had in Central Bank), hammered on this point:

Basic is surely a sufficient response to the argument that a complaint alleging that deceptive acts which had a material effect on the price of a listed stock should be dismissed because the plaintiffs were not subjectively aware of the deception at the time of the securities' purchase or sale. This Court has not held that investors must be aware of the specific deceptive act which violates $\S 10(b)$ to demonstrate reliance. ...

The fraud-on-the-market presumption helps investors who cannot demonstrate that they, themselves, relied on fraud that reached the market. But that presumption says nothing about causation from the other side: what an individual or corporation must do in order to have "caused" the misleading information that reached the market. The Court thus has it backwards when it first addresses the fraud-on-the-market presumption, rather than the causation required. ${ }^{160}$

\footnotetext{
${ }^{157}$ PSLRA § 104, 109 Stat. 757 (codified at 15 U.S.C. § 78t(e)). Congress recently expanded the SEC's authority by reducing the state of mind requirement from knowledge to recklessness. See Dobb-Frank.

${ }^{158}$ Stoneridge, 552 U.S. at 163.

${ }^{159}$ Id. at $163-164$.

${ }^{160}$ Stoneridge, 552 U.S. at 170-171(Stevens, J., dissenting).
} 


\section{Securities Law in the Roberts Court}

It is fair to say that Justice Blackmun, who wrote Affiliated Ute and Basic, would have reached a different outcome in Stoneridge. As Blackmun noted in his memo to the file after reviewing the Affiliated Ute briefs, "I feel we should plump for a high standard in this area, and that this is in line with the intent of Congress in enacting the legislation."161 Blackmun set a "high standard" in Affiliated Ute and Basic; Kennedy ratcheted it down in Central Bank, and again in Stoneridge. Stevens pushed, unsuccessfully, to further Blackmun's legacy in expanding the private cause of action under Rule $10 b-5 .^{162}$

The point is not that one side or the other is correct in their divining of congressional intent. That quest seems futile. Rule $10 b-5$ 's reliance element is nowhere to be found in the language of $\S 10(b)$ or Rule 10b-5; the Court borrowed it from the common law of deceit. Despite that borrowing, the Court does not refer to the common law when it is interpreting the reliance requirement for the Rule $10 \mathrm{~b}-5$ private cause of action. In Stoneridge, Kennedy brusquely rejected the argument that the plaintiffs had adequately pled reliance under common law standards: "Even if the assumption is correct, it is not controlling. Section 10(b) does not incorporate common-law fraud into federal law."163 ${ }^{16}$ would seem more accurate to say that the incorporation is selective: The Court borrows the common law element of reliance, without really explaining why, but then disregards it when inconvenient. Kennedy's rejection of common law standards in Stoneridge suggests that the Court is charting its own common law course. The Court's interventions, however, are episodic; the Court takes an insufficient

\footnotetext{
${ }^{161}$ Harry A. Blackmun, Memo, No. 70-78 - Affiliated Ute Citizens v. United States (10/18/71), Harry A. Blackmun Papers, Library of Congress.

162 Stoneridge, 552 U.S. at 175-176 (Stevens, J., dissenting) ("A theme that underlies the Court's analysis is its mistaken hostility towards the $\S 10$ (b) private cause of action. The Court's current view of implied causes of actions is that they are merely a relic of our prior heady days.") (citations and internal quotation marks omitted).

${ }^{163}$ Stoneridge, 552 U.S. at 162.
} 


\section{Securities Law in the Roberts Court}

number of securities cases to develop this "common law" in any meaningful manner. Will the larger number of cases heard by the Roberts Court change this? Given the framing of the debates in these cases, it seems unlikely.

The two-part interpretive approach framed by Kennedy in Central Bank purports to depart from the common law interpretation that typified Rule $10 b-5$ for many years. Cases like Affiliated Ute and Basic focused on assuring recovery for the plaintiffs, with little regard for the costs created by private litigation. Generally, the Court used a common law, policy-oriented approach when it was expanding Rule $10 \mathrm{~b}-5$, viewing the private cause of action as an "essential supplement" to the SEC's enforcement efforts. ${ }^{164}$ Central Bank promised a textual, formalist approach when the Court turned to reining in the reach of the private cause of action. Stoneridge, with its return to a fuzzy "requisite causal connection" notion of reliance, ${ }^{165}$ fails to deliver on that promise, instead returning to an essentially common law mode of decisionmaking. The opinion does little more than tell us that the defendants' conduct was "too remote" for plaintiffs to rely on. ${ }^{166}$ The bottom line is that both factions of the Court manipulate the reliance element to achieve their preferred scope for the securities fraud cause of action. More recently, the faction resisting expansion has prevailed.

\section{Foreign Class Actions}

The Roberts Court's most recent foray into securities class action practice involved the extra-territorial reach of the federal securities laws. Morrison v. National Australia Bank Ltd.

\footnotetext{
164 Tellabs, Inc. v. Makor Issues \& Rights, Ltd., 127 S. Ct. 2499, 2504 (2007).

165 Stoneridge, 552 U.S. at 159 (quoting Basic, 485 U.S. at 243).

${ }^{166}$ Stoneridge, 552 U.S. at 161.
} 


\section{Securities Law in the Roberts Court}

was a so-called "F-cubed" securities class action: Australian investors who had purchased common shares of the largest Australian bank over the Australian Stock Exchange.

The district court dismissed the case for lack of subject matter jurisdiction and the Second Circuit affirmed. ${ }^{167}$ The Second Circuit had developed a two-prong test to determine whether the application of the U.S. securities laws was appropriate. Jurisdiction to adjudicate a $\S 10$ (b) claim would exist if the plaintiff could show either: (1) an effect of American securities markets or investors; or (2) significant conduct relating to the fraud taking place in the United States. ${ }^{168}$ The National Australia plaintiffs disclaimed reliance on the effects prong because the American investor who purchased National Australia's ADRs on the New York Stock Exchange was dismissed from the litigation at an early stage. ${ }^{169}$ The conduct at issue was the inflation of the value of assets of Homeside, a wholly-owned subsidiary of National Australia operating a mortgage servicing business out of Florida. The plaintiffs alleged that Homeside had exaggerated the value of its mortgage servicing contracts and that these exaggerated figures were passed through to National Australia's consolidated balance sheet, thereby causing National Australia's stock to trade at an inflated value. ${ }^{170}$ When National Australia eventually wrote down the value of Homeside's assets, the price of National Australia's stock plummeted and the plaintiffs filed suit. ${ }^{171}$ The Second Circuit, however, said that the federal courts lacked

\footnotetext{
${ }^{167} 2006$ WL 3844465 (S.D.N.Y. 2006) and 547 F.3d 167 (2 ${ }^{\text {nd }}$ Cir. 2008), respectively.

${ }^{168}$ SEC v. Berger, 322 F.3d 187, 192-193 ( $2^{\text {nd }}$ Cir. 2003).

${ }^{169}$ In re National Australia Bank Securities Litigation, No. 03 Civ. 6537(BSJ), 2006 WL 3844465, *9 (S.D.N.Y., Oct.25, 2006).

${ }^{170}$ National Australia, 130 S. Ct. at 2875-2876.

${ }^{171}$ National Australia, 130 S. Ct. at 2876.
} 
jurisdiction over the Australian investors' claims because conduct in Australia was the source of the alleged misrepresentations. ${ }^{172}$

The plaintiffs filed a petition for certiorari, and the Supreme Court asked for the Solicitor General's views. In the government's amicus brief, the Solicitor General argued that the Second Circuit had erred in treating the question as jurisdictional, rather than relating to the merits. ${ }^{173}$ Turning to the merits, the government argued that the Second Circuit was at once too restrictive and too generous in conferring jurisdiction over $\S 10(\mathrm{~b})$ claims. Too restrictive, because the Second Circuit had held that private plaintiffs and the SEC should be held to the same standard; the government argued that it should be held to a lower standard. ${ }^{174}$ Perhaps taking their cue from Stoneridge, the government urged that the correct standard for enforcement and criminal actions was what it characterized as the full reach of $\S 10(b)$ : "a transnational securities fraud violates Section 10(b) when the fraud involves significant conduct in the United States that is material to the fraud's success." ${ }^{175}$ For private plaintiffs, additional restrictions were in order; specifically, a private plaintiff should be required to "establish not simply that his loss resulted from the fraudulent scheme as a whole, but that the loss resulted directly from the component of the fraud that occurred in the United States."176

\footnotetext{
172 Morrison v. National Australia Bank, 547 F.3d 167, 176 (2 ${ }^{\text {nd }}$ Cir. 2008) ("NAB, not HomeSide, is the publicly traded company, and its executives-assisted by lawyers, accountants, and bankers-take primary responsibility for the corporation's public filings, for its relations with investors, and for its statements to the outside world.").

${ }^{173}$ Brief for the United States as Amicus Curiae Supporting Respondents, Morrison v. National Australia Bank Ltd., Docket \# 08-8-1191, at 9-13.

${ }^{174}$ Brief for the United States as Amicus Curiae Supporting Respondents, Morrison v. National Australia Bank Ltd., Docket \# 08-8-1191, at 30 (criticizing holding of SEC v. Berger, 322 F.3d 187 ( $2^{\text {nd }}$ Cir. 2003) that same jurisdictional standard applies to private plaintiffs and SEC).

${ }^{175}$ Brief for the United States as Amicus Curiae Supporting Respondents, Morrison v. National Australia Bank Ltd., Docket \# 08-8-1191, at 16.

176 Brief for the United States as Amicus Curiae Supporting Respondents, Morrison v. National Australia Bank Ltd., Docket \# 08-8-1191, at 26.
} 


\section{Securities Law in the Roberts Court}

The SEC's efforts to throw the plaintiffs under the bus were to no avail. The Court rejected not only the plaintiffs' claim, but also the government's argument that private actions should be held to a higher standard. Justice Scalia wrote for the majority; he was clearly a jurist on a mission. After summarily dispatching the Second Circuit's "threshold error" in treating the question as jurisdictional, ${ }^{177}$ Scalia turned to dismantling the Second Circuit's conduct and effects test. The Second Circuit, noting the silence of $\S 10(b)$ on extraterritorial effect, had taken it upon itself to divine what Congress would have done if it had thought about the question. What would this hypothetical Congress do? (1) Protect American investors; and (2) Discourage fraudsters from operating out of the United States. Notwithstanding the plausibility of these goals, Scalia argued that the Second Circuit's test was wrong from its inception. The Second Circuit's test failed to accord due weight to the Court's longstanding presumption against giving statutes extra-territorial effect: "When a statute gives no clear indication of an extraterritorial application, it has none." ${ }^{178}$ The Second Circuit had gone off the tracks when it had inferred from $\S 10(b)$ 's silence on the question of extra-territorial application an invitation to engage in "judicial-speculation-made-law-divining what Congress would have wanted if it had thought of the situation before the court." ${ }^{179}$ That judicial speculation was bad enough, but it had led to "unpredictable and inconsistent application of $\S 10(\mathrm{~b})$ to transnational cases."180 From Scalia's perspective, “[t]here is no more damning indictment of the 'conduct' and 'effects' tests than the Second Circuit's own declaration that 'the presence or absence of any single factor which was considered significant in other cases ... is not necessarily dispositive

\footnotetext{
${ }^{177}$ National Australia, 130 S. Ct. at 2876-2877.

${ }^{178}$ National Australia, 130 S. Ct. at 2878.

${ }^{179}$ National Australia, 130 S. Ct. at 2881.

${ }^{180}$ National Australia, 130 S. Ct. at 2880 (citing numerous commentators).
} 
in future cases.'”181 Judicially created out of whole cloth, and unpredictable to boot? A recipe for a Scalia tirade on the proper role of judges. The Solicitor General's somewhat cosmetic repackaging of that test fared no better. ${ }^{182}$ Nor was the SEC's endorsement of that test entitled to deference, as it was premised on the judicial errors committed by the Second Circuit. ${ }^{183}$

And what does Scalia see as the proper role of judges? Reading statutes for their ordinary meaning. Having debunked the Second Circuit's approach, Scalia was forced to devise his own rule of decision. Unsurprisingly, he argued that his preferred test was grounded the text of the statute. Examining the text of $\S 10(b)$, Scalia found that the focus was not on deception, but rather, the provision's requirement that deception, to be actionable, must be "in connection with the purchase or sale of securities." ${ }^{184}$ The purchase or sale transaction, Scalia thought, was the touchstone of what Congress sought to regulate, and purchasers and sellers were the parties that Congress sought to protect. This analysis of $\S 10(b)$ 's text led Scalia to his test for its application: "transactions in securities listed on domestic exchanges, and domestic transactions in other securities." ${ }^{185}$ Scalia's conclusion derived from the statutory text was bolstered by the structure of the statute, ${ }^{186}$ as well as "the probability of incompatibility with the applicable laws of other countries."187 On this point, the Court appears to have been swayed by the amicus briefs filed by a number of foreign governments, who protested

\footnotetext{
${ }^{181}$ National Australia, 130 S. Ct. at 2879 (quoting IIT v. Cornfeld, 619 F.2d 909, 918 (1980).

${ }^{182}$ National Australia, 130 S. Ct. at 2886.

${ }^{183}$ National Australia, 130 S. Ct. at 2887-2888 ("Since the Commission's interpretations relied on cases we disapprove, which ignored or discarded the presumption against extraterritoriality, we owe them no deference.").

${ }^{184}$ National Australia, 130 S. Ct. at 2884.

${ }^{185}$ National Australia, 130 S. Ct. at 2884.

${ }^{186}$ National Australia, 130 S. Ct. at 2885 (parsing § 30(a) \& (b) of the Exchange Act, which provide for limited extrterritorial effect).

${ }^{187}$ National Australia, 130 S. Ct. at 2885.
} 


\section{Securities Law in the Roberts Court}

vigorously the exposure of companies headquartered in their jurisdictions to American class actions. $^{188}$

This last point bears examining. When the Second Circuit was developing its conduct and effects test, the United States was the only game in town for securities class actions, so the Second Circuit's imperialism was not directly stepping on the toes of any foreign government. Many countries object, however, to the exposure of their companies to our class action regime, a point noted by Justice Scalia. ${ }^{189}$ Most countries remain skeptical of the utility of the class action as an enforcement device. A handful, however, most notably Australia and Canada, recently have adopted securities class action regimes of their own. ${ }^{190}$ The conflict becomes more acute when those companies are also subject to class action suit in their home jurisdictions. The threat of overdeterrence posed by double liability is obvious.

On the opposite end of the spectrum was Justice Stevens' concurrence. Continuing his lonely defense of the Rule 10b-5 private cause of action, Stevens embraced the Second Circuit's conduct and effects test, and more generally, the judiciary's role in creating the $\S 10$ (b) cause of action.

The development of $\S 10(\mathrm{~b})$ law was hardly an instance of judicial usurpation. Congress invited an expansive role for judicial elaboration when it crafted such an open-ended statute in 1934. And both Congress and the Commission

\footnotetext{
${ }^{188}$ National Australia, 130 S. Ct. at 2885-2886 (citing briefs filed by Australia, Great Britain, and France).

${ }^{189}$ National Australia, 130 S. Ct. at 2886 ("While there is no reason to believe that the United States has become the Barbary Coast for those perpetrating frauds on foreign securities markets, some fear that it has become the Shangri-La of class-action litigation for lawyers representing those allegedly cheated in foreign securities markets.")

${ }^{190}$ See Ashley Black and Kathleen Harris, "Corporate Class Actions in Australia," Mallesons Stephen Jacques, June 2006 (available at www.mallesons.com/publications). On Canada, see A.C. Pritchard \& Janis P. Sarra, Securities Class Actions Move North: A Doctrinal and Empirical Analysis of Securities Class Actions in Canada , 47 Alberta L. Rev. 881 (2010).
} 
subsequently affirmed that role when they left intact the relevant statutory and regulatory language, respectively, throughout all the years that followed. ${ }^{191}$

As usual, Stevens gave considerable weight to the fact the Second Circuit test was longstanding. ${ }^{192}$ More pointedly, while agreeing with the Court's conclusion, he reiterated his lament from Stoneridge, dissenting from "from the Court's continuing campaign to render the private cause of action under $\S 10(b)$ toothless."193

The National Australia decision produced an immediate, if somewhat clumsy, reaction from Congress. Less than a month after the decision was handed down, Congress passed the Dodd-Frank Wall Street Reform and Consumer Protection Act, a wholesale reform of financial regulation in the wake of the recent financial crisis. Among its reforms was one aimed at overruling the result in National Australia, as the bill's legislative history makes clear: "“This bill's provisions concerning extraterritoriality ... are intended to rebut [National Australia]'s presumption by clearly indicating that Congress intends extraterritorial application in cases brought by the SEC or the Justice Department." ${ }^{194}$ Unfortunately, Congress enacted language ensuring only that the courts would have jurisdiction to hear cases with extraterritorial application, not that $\S 10$ (b) would have extraterritorial application. ${ }^{195}$ Thus, Congress repeated the Second Circuit's error of treating the scope of the law as jurisdictional, rather than a merits question. Even if the courts ignore the provision's language and apply the provision to expand the substantive scope of $\S 10(b)$, it applies only to actions brought by the SEC or the Justice

\footnotetext{
${ }^{191}$ National Australia, 130 S. Ct. at 2890 (Stevens, J. concurring).

192 National Australia, 130 S. Ct. at 2895 (Stevens, J. concurring) (criticizing the majority for paying "short shrift ... to the accumulated wisdom and experience of the lower courts.").

193 National Australia, 130 S. Ct. at 2895 (Stevens, J. concurring) (quoting Stoneridge, 552 U.S., at 175, (Stevens J., dissenting)).

${ }^{194}$ Remarks of Congressman Kanjorski, Cong. Record H5237 (June 30, 2010).

195 H.R. 4173, $111^{\text {th }}$ Cong., $§ 929 P(b)(2010)$.
} 


\section{Securities Law in the Roberts Court}

Department. (Private plaintiffs won only a study by the SEC, which is required to report to Congress within eighteen months of the Dodd-Frank passage.) $)^{196}$ Congress's reaction is rather humorous in light of Justice Scalia's claim that one benefit of a clear presumption against extraterritorial application is that it "preserv[es] a stable background against which Congress can legislate with predictable effects." ${ }^{197}$ The "predictable effects" that Justice Scalia claims for his rule are premised on an assumption of minimal competence on the part of Congress. That assumption proved unjustified in this case; it does not appear that anyone on Capitol Hill bothered to read Justice Scalia's opinion. We will have to wait to see if courts follow DoddFrank's legislative history or its text when it comes to interpreting the extraterritorial provision.

\section{E. Anti-Plaintiff Court?}

At the time that Roberts was nominated to be the Chief Justice, there were claims that he would head a "pro business" Court. The decisions of Roberts Court, however, if anything show a bias toward the status quo. Tellabs and Jones both rebuffed efforts by lower courts to narrow the gates through which securities class actions could proceed. A fair-minded scorekeeper would have to put these decisions in the plaintiff's column, despite the defendant's nominal victory in Tellabs. In Tellabs, the Supreme Court reversed a lenient Seventh Circuit decision for drawing inferences with respect to scienter, but replaced it with a standard that is nonetheless relatively generous to plaintiffs. In so doing, the Court rejected a more stringent standard adopted by a number of lower courts and urged by both the governments as amicus and the dissenting justices. On balance, the Tellabs decision was likely a net benefit to the plaintiffs' bar. Both Tellabs and Jones are cautious decisions, grounded in

\footnotetext{
196 H.R. 4173, $111^{\text {th }}$ Cong., $§ 929 Y(2010)$.

197 National Australia, 130 S. Ct. at 2881.
} 


\section{Securities Law in the Roberts Court}

conventional approaches to statutory interpretation. Stoneridge and National Australia, by contrast adopt considerably more aggressive language. Both decisions rebuffed efforts by the plaintiffs' bar to expand the pool of potential defendants; Stoneridge to third party defendants, National Australia to foreign companies. The perceived disregard of Supreme Court precedents by lower courts in these areas were calculated to provoke hot button responses from individual justices. In Stoneridge, it was Justice Kennedy, who likely saw "scheme liability" as an attempt to do an end run around the holding of his Central Bank opinion. In National Australia, Justice Scalia was provoked by the Second Circuit's disregard for the Court's presumption against extraterritorial application. Accordingly, it should come as no surprise that the rhetoric in Stoneridge and National Australia takes on a more muscular tone. These decisions reflect the Roberts Court bringing the lower courts to heel. It is reaction to the lower courts' waywardness, rather than any agenda peculiar to the securities laws, that drives the more strident tenor of those decisions.

\section{Conclusion}

The Roberts Court's work in the field of securities law demonstrates what happens when a court of general jurisdiction is charged with making decisions in an area with which it is unfamiliar. Analysis of the Court's decisions yields few, if any, common threads tying them together as a body of work. Whatever direction the securities laws take in the Supreme Court, do not expect opinions to grapple more seriously with the interplay between securities law and the securities markets anytime soon. The randomness of the Roberts Court's securities jurisprudence results in part from the stream of cases that make their way on to the Court's 


\section{Securities Law in the Roberts Court}

docket. It is also a product, however, of the absence of any individual justice having an interest in the field. A comparison with Lewis Powell's tenure on the Court illustrates the point. Powell drew on his background as a corporate lawyer to push the Court in a particular direction during his time on the Court, reining in securities class actions and imposing a common law framework on the SEC'S vendetta against insider trading. ${ }^{198}$

The Roberts Court does not have a figure like Powell in the field of securities law. It agrees to hear securities cases because there is a circuit split, not because it is anxious to impose its mark on the field of securities law. The debate that engages the justices in these cases do not come from the field of securities laws, but rather, are more general: statutory interpretation, the use of legislative history, the presumption against the extraterritorial application of legislation, etc.

What does this indifference mean for securities law? First, it may mean that the path of law is somewhat unpredictable. It is hard to know when a Justice will be so galvanized by a particular issue that he takes ownership of it, as Justice Kennedy appears to have done with aiding and abetting. Second, absent such an issue, there is likely to be a presumption in favor of the position taken by the government. This attitude of occasional deference means that the relationship between the SEC and the Solicitor General takes on critical importance. If the SEC can persuade the Solicitor General, its position is likely to prevail in the Roberts Court. With a Democrat currently in the White House, the SEC and the Solicitor General are likely to see eyeto-eye in the near term. If the Republicans regain control of the White House, that could

\footnotetext{
${ }^{198}$ See Pritchard, supra note
} 


\section{Securities Law in the Roberts Court}

change, but for now, the government is likely to take positions that maximize the SEC's reach as it did in National Australia (albeit unsuccessfully).

No justice is likely to push securities law in a more aggressive direction than the SEC; the retirement of Justice Stevens means that there is no one left on the Court with any pretensions of being an activist in the field, particularly in the area of the private right of action. Justice Ginsberg, writing for the Tellabs majority, made it clear that the Court intends to defer to Congress in this area: "It is the federal lawmaker's prerogative ... to allow, disallow, or shape the contours of - including the pleading and proof requirements for - § 10(b) private actions." ${ }^{199}$ This language suggests we should not expect the Court to be anything more than a passive observer here; major changes, if any, will come from Congress.

The Roberts Court's cautious attitude is a departure for the Court. The Court's treatment of the basic question of the existence of the implied private right of action in Stoneridge sends a clear signal that the Court's expansionist days are over in the field of securities law. Kennedy made it clear that the initial implication of a private cause of action had been a mistake; under current doctrine, private causes of action are based only on explicit instruction from Congress. ${ }^{200}$ Having recognized the mistake, the Court was not going to compound the error: "Concerns with the judicial creation of a private cause of action caution against its expansion. The decision to extend the cause of action is for Congress, not for us. Though it remains the law, the $\S 10(\mathrm{~b})$ private right should not be extended beyond its present

\footnotetext{
199 Tellabs, 551 U.S. at 327.

${ }^{200}$ Id. ("Though the rule once may have been otherwise, it is settled that there is an implied cause of action only if the underlying statute can be interpreted to disclose the intent to create one.") (citations omitted).
} 


\section{Securities Law in the Roberts Court}

boundaries." 201 Thus, Stoneridge stands for the proposition that the Rule $10 \mathrm{~b}-5$ cause of action

is now frozen, at least when it comes to the expansion of liability by the Court. ${ }^{202}$ Expansion of the cause of action will have to come from Congress, if it is to come at all. This attitude of deference is a far cry from the heady days of the Warren Court, or even Justice Blackmon's expansionist push in Basic, Inc. v. Levinson. Securities law in the Roberts Court is likely to be focused on maintaining the status quo.

201 Id. at 773.

${ }^{202}$ See id. ("when [the aiding and abetting provision of the PSLRA] was enacted, Congress accepted the $\S 10(b)$ private cause of action as then defined but chose to extend it no further."). 